bioRxiv preprint doi: https://doi.org/10.1101/2021.02.25.432862; this version posted February 25,2021 . The copyright holder for this preprint (which was not certified by peer review) is the author/funder, who has granted bioRxiv a license to display the preprint in perpetuity. It is made available under aCC-BY-NC-ND 4.0 International license.

\title{
Systems biology analysis identifies TCF7L1 as a key regulator of metastasis in Ewing sarcoma
}

Florencia Cidre-Aranaz ${ }^{1,2}$, Jing Li ${ }^{1,2}$, Tilman L. B. Hölting ${ }^{3}$, Martin F. Orth ${ }^{3}$, Roland Imle ${ }^{1,4,5,6}$, Stefanie Kutschmann ${ }^{1,2}$, Giulia Ammirati ${ }^{7}$, Katharina Ceranski ${ }^{1,2}$, Martha Julia CarreñoGonzalez $^{1,2}$, Merve Kasan ${ }^{3}$, Aruna Marchetto ${ }^{3}$, Cornelius M. Funk ${ }^{1,2}$, Felix Bestvater ${ }^{8}$, Simone Bersini $^{7}$, Chiara Arrigoni ${ }^{7}$, Matteo Moretti ${ }^{7,9}$, Laura Romero-Pérez ${ }^{1,2}$, Ana Banito ${ }^{1,4}$, Shunya Ohmura $^{1,2}$, Julian Musa ${ }^{1,2,10}$, Thomas Kirchner ${ }^{3}$, Maximilian M. L. Knott ${ }^{3, *}$, Thomas G. P. Grünewald ${ }^{1,2,3,9,11 \S, *}$

1 Hopp-Children's Cancer Center (KiTZ), Heidelberg, Germany

2 Division of Translational Pediatric Sarcoma Research (B410), German Cancer Research Center (DKFZ), German Cancer Consortium (DKTK), Heidelberg, Germany

3 Max-Eder Research Group for Pediatric Sarcoma Biology, Institute of Pathology, Faculty of Medicine, LMU Munich, Munich, Germany

4 Soft-Tissue Sarcoma Junior Research Group, German Cancer Research Center (DKFZ), German Cancer Consortium (DKTK), Heidelberg, Germany

5 Faculty of Biosciences, Heidelberg University, Heidelberg, Germany.

6 Division of Pediatric Surgery, Department of General, Visceral and Transplantation Surgery, University Hospital Heidelberg, Heidelberg, Germany.

7 Regenerative Medicine Technologies Laboratory, Ente Ospedaliero Cantonale (EOC), Lugano, Switzerland

8 Light Microscopy Facility (W210), German Cancer Research Center (DKFZ), German Cancer Consortium (DKTK), Heidelberg, Germany

9 Biomedical Sciences Faculty, Università della Svizzera Italiana (USI), Lugano, Switzerland

10 Department of General, Visceral and Transplantation Surgery, Heidelberg University Hospital, Heidelberg, Germany

11 Institute of Pathology, Heidelberg University Hospital, Heidelberg, Germany

* M.M.L.K. and T.G.P.G. share senior authorship

\section{§ Correspondence}

Thomas G.P. Grünewald, MD, PhD

Division Head, Division of Translational Pediatric Sarcoma Research (B410)

German Cancer Research Center (DKFZ) \& Hopp-Children's Cancer Center (KiTZ)

Im Neuenheimer Feld 280, 69210 Heidelberg, Germany

Phone +49-6221-42-3718

Fax +49-6221-42-3721

Email t.gruenewald@kitz-heidelberg.de

Word count

2,620 (not including Abstract, Methods, and Figure Legends)

Display items

Running title

Key words
4 Figures, 3 Supplementary Figures, 4 Supplementary Tables

TCF7L1 inhibits metastasis in Ewing sarcoma

Ewing sarcoma, TCF7L1, pediatric oncology, metastasis, systems biology 
bioRxiv preprint doi: https://doi.org/10.1101/2021.02.25.432862; this version posted February $25,2021$. The copyright holder for this preprint (which was not certified by peer review) is the author/funder, who has granted bioRxiv a license to display the preprint in perpetuity. It is made available under aCC-BY-NC-ND 4.0 International license.

Cidre-Aranaz et al.

TCF7L1 inhibits metastasis in Ewing sarcoma

\section{ABSTRACT}

Identification of cancer stemness genes is crucial to understanding the underlying biology of therapy resistance, relapse, and metastasis. Ewing sarcoma (EwS) is the second most common bone tumor in children and adolescents. It is a highly aggressive cancer associated with a dismal survival rate $(<30 \%)$ for patients with metastatic disease at diagnosis ( $25 \%$ of cases). Hence, deciphering the underlying mechanisms of metastasis is imperative. EwS tumors are characterized by a remarkably 'silent' genome with a single driver mutation generating an oncogenic fusion transcription factor (EWSR1-ETS). Thus, EwS constitutes an ideal model to study how perturbation of a transcriptional network by a dominant oncogene can mediate metastasis, even though canonical metastasis-associated genes are not mutated.

Here, through the implementation of an integrative systems biology approach, we identified transcription factor 7 like $1(T C F 7 L 1$, alias $T C F 3)$ as a prognostically-relevant and EWSR1ETS suppressed determinant of metastasis in EwS. We demonstrated that conditional TCF7L1 re-expression significantly reduces EwS single-cell migration, invasion and anchorageindependent growth in $3 \mathrm{D}$ assays in vitro, and tumorigenesis in vivo mediated by its DNA binding domain. In primary EwS tumors as well as in functional orthotopic in vivo models, low TCF7L1 expression was associated with pro-metastatic gene signatures and a much higher migratory and metastatic capacity of EwS cells, which correlated with poor outcome of EwS patients.

Collectively, our findings establish TCF7L1 as a major regulator of metastasis in EwS, which may be utilized as a prognostic biomarker and open inroads to future therapeutic intervention. 
bioRxiv preprint doi: https://doi.org/10.1101/2021.02.25.432862; this version posted February $25,2021$. The copyright holder for this preprint (which was not certified by peer review) is the author/funder, who has granted bioRxiv a license to display the preprint in perpetuity. It is made available under aCC-BY-NC-ND 4.0 International license.

Cidre-Aranaz et al.

TCF7L1 inhibits metastasis in Ewing sarcoma

\section{INTRODUCTION}

Cancer stemness genes are a cornerstone governing therapy resistance, relapse, and metastasis $^{1,2}$. In carcinomas, many stemness/metastasis genes and associated pathways are frequently activated through somatic mutations including copy-number changes and base substitutions ${ }^{3,4}$. Surprisingly, pediatric tumors -despite being largely composed of undifferentiated stem cell-like cells- typically present low numbers of mutations that generally do not involve canonical stemness/metastasis-associated genes ${ }^{5}$.

Ewing sarcoma (EwS) is a highly aggressive bone and soft-tissue cancer with great propensity for early hematological metastasis mainly affecting children, adolescents, and young adults ${ }^{6}$. In past decades, the development and implementation of multimodal chemotherapeutic regimens for the treatment of patients with localized (i.e. non-metastatic) EwS has drastically increased overall survival $^{6}$. However, the clinical outcome for patients with metastatic disease at diagnosis $(\sim 25 \%$ of cases) or relapse remains unacceptably poor ( $<30 \%$ survival rates), even with the application of highly toxic therapies ${ }^{7}$. Hence, it is crucial to unravel the underlying biologic mechanisms that drive stemness and metastasis in EwS to open new therapeutic avenues.

Genetically, EwS ranges among the tumors with the fewest mutations identified to date ${ }^{8}$. In fact, most EwS tumors exhibit only a single recurrent mutation, that is a chromosomal translocation fusing the EWSRI gene and variable members of the ETS family of transcription factors $(\mathrm{TFs})^{9,10}$. EWSRl-ETS encode aberrant TFs, which massively rewire the EwS transcriptome and promote stem cell features ${ }^{11-13}$; even though classical stemness- and metastasis-associated genes remain not mutated ${ }^{14-16}$. Although EwS is genetically well characterized, its cell of origin remains unknown. Morphologically, EwS tumors resemble blastemal tissues composed of highly undifferentiated cells without overt cellular hierarchy, wherefore it is often described as an 'embryonal tumor' ${ }^{9}$. Indeed, ectopic EWSR1-FLI1 expression can transcriptionally 'reprogram' human pediatric mesenchymal stem cells by 
bioRxiv preprint doi: https://doi.org/10.1101/2021.02.25.432862; this version posted February 25,2021 . The copyright holder for this preprint (which was not certified by peer review) is the author/funder, who has granted bioRxiv a license to display the preprint in perpetuity. It is made available under aCC-BY-NC-ND 4.0 International license.

Cidre-Aranaz et al.

TCF7L1 inhibits metastasis in Ewing sarcoma

upregulation of embryonic stem cell genes generating cells with cancer stem cell-like properties $^{13}$.

The processes of metastasis and stemness are intimately linked ${ }^{17}$. In fact, accumulating evidence suggests that tumor cells of highly undifferentiated malignancies, such as EwS, may reside in a 'metastable' state equipping them with proliferative and migratory traits (for review see ${ }^{18}$ ), which has been previously framed by the integrative 'migratory stem cell' concept ${ }^{19}$. Given the rather simple genetic make-up of EwS, this disease may constitute an ideal model to study how perturbation of a transcriptional network by a dominant oncogene can mediate stemness and metastasis features. Although several groups identified particular EWSR1-ETSdriven genes or pathways that likely play a role in maintenance of stemness, and hence in the establishment of a more metastatic phenotype $\mathrm{e}^{20}$, a systematic understanding of this process and of its clinical implications is still lacking.

In the current study, we explored how EWSR1-ETS rewires the EwS transcriptome on a systems biology level, and identified the transcription factor 7 like 1 (TCF7L1, alias TCF3), a stem-cell differentiation-related transcription factor involved in the Wnt pathway ${ }^{21}$, as key downstream regulator of the EWSR1-ETS-mediated stemness and metastasis features. By combining preclinical and clinical data, we show that EWSR1-ETS suppresses $T C F 7 L 1$, which promotes anchorage-independent growth and metastasis through deregulation of developmental and migration-associated gene signatures. Moreover, we show that TCF7L1 expression is negatively correlated with poor patient outcome, collectively shedding new light on the underlying biological mechanisms governing stemness and metastasis in EwS, which may open inroads to future clinical exploitation. 
bioRxiv preprint doi: https://doi.org/10.1101/2021.02.25.432862; this version posted February $25,2021$. The copyright holder for this preprint (which was not certified by peer review) is the author/funder, who has granted bioRxiv a license to display the preprint in perpetuity. It is made available under aCC-BY-NC-ND 4.0 International license.

Cidre-Aranaz et al.

TCF7L1 inhibits metastasis in Ewing sarcoma

\section{RESULTS}

\section{Application of a systems biology approach identifies TCF7L1 as a prognostically relevant}

\section{EWSR1-ETS-regulated network hub}

To identify highly relevant EWSRI-ETS target genes involved in the stemness/metastasis axis we analyzed transcriptome profiles of $5 \mathrm{EwS}$ cell lines with or without shRNA-mediated knockdown of EWSR1-FLI1 or $-E R G$ (knockdown $<20 \%$ of baseline expression) for $96 \mathrm{~h}$ according to the workflow depicted in Fig. 1a. This analysis yielded a list of 348 differentially expressed genes (DEGs) being up- or downregulated $(|\log 2 \mathrm{FC}| \geq 1.5)$ after knockdown of EWSR1-FLI1 or -ERG across all cell lines (Supplementary Table 1). We next filtered these DEGs for genes being annotated with the gene ontology (GO) term 'Regulation of Cell Differentiation' using PantherDB, which was significantly enriched among the EWSR1-ETS regulated DEGs $\left(P=4.93 \times 10^{-12}\right.$, false-discovery rate $\left.(\mathrm{FDR})=1.97 \times 10^{-9}\right)$. Based on the resulting 76 DEGs (Supplementary Table 2), we carried out a network analysis using Cytoscape and the GeneMania plugin using available information on pathway, physical, and genetic interactions $^{22}$ (Fig. 1b,c). To identify key hubs within this network that may have clinical relevance and may be important for understanding downstream effects of EWRSI-ETS, we focused on highly interconnected TFs $(n=11)$ whose expression correlated with overall survival of EwS patients. To this end, we further filtered the list of TFs for those that exhibited at least 10 interactions and that showed a significant $(P<0.05$, Mantel-Haenszel test $)$ association with overall survival in a cohort of $166 \mathrm{EwS}$ patients with matched gene expression and clinical data $^{23}$. This analytical process yielded two TFs whose expression nominally correlated with patient overall survival (Supplementary Table 3). However, after adjustment for multiple testing, transcription factor 7 like 1 (TCF7L1, alias TCF3) emerged as the most promising candidate for functional follow-up (nominal $P=0.0057 ; P=0.0228$ Bonferroni-adjusted) (Fig. 1d). Notably, TCF7L1 appeared to be downregulated by EWSR1-ETS since microarray data of each respective fusion oncogene knockdown for $96 \mathrm{~h}$ induced on average a $\sim 3$-fold upregulation 
bioRxiv preprint doi: https://doi.org/10.1101/2021.02.25.432862; this version posted February $25,2021$. The copyright holder for this preprint (which was not certified by peer review) is the author/funder, who has granted bioRxiv a license to display the preprint in perpetuity. It is made available under aCC-BY-NC-ND 4.0 International license.

Cidre-Aranaz et al.

TCF7L1 inhibits metastasis in Ewing sarcoma

of TCF7L1 (Supplementary Table 4), which was confirmed in $5 \mathrm{EwS}$ cell lines with independent assays by qRT-PCR (on average $\sim 6$-fold upregulation (Supplementary Fig. 1a.). This finding was validated in xenografts of A673 cells with/without conditional knockdown of EWSR1-FLI1 (A673/TR/shEF1 cells) at the mRNA and protein level (Supplementary Fig. 1b).

Collectively, these data highlight $T C F 7 L 1$ as a prognostically relevant, EWSR1-ETS-regulated network hub involved in the regulation on stemness/metastasis in EwS.

\section{TCF7L1 re-expression inhibits tumorigenesis in vitro and in vivo}

Little is known about the precise cellular function of $T C F 7 L 1$ in cancer. However, prior reports suggested that it may have either oncogenic or tumor suppressor properties depending on the cellular context ${ }^{24-28}$. To explore its potential role in EwS, we first analyzed the TCF7L1 expression pattern across 18 cancer entities using publicly available microarray data from the Cancer Cell Line Encyclopedia (CCLE) ${ }^{29}$ and from an own study that compiled well-curated microarray data from the same cancer entities ${ }^{30}$. Surprisingly, $T C F 7 L 1$ was very highly, but still variably, expressed in EwS cell lines and primary tumors (Fig. 2a).

To obtain first clues on its potential function in primary EwS, we performed Weighted Gene Correlation Network Analysis (WGCNA) based on enriched gene-sets ${ }^{31}$ in TCF7L1-correlated genes in 166 EwS tumors. Strikingly, this analysis showed that EwS tumors with low TCF7L1 expression were enriched in embryonic pathways (Fig. 2b). Although TCF7L1 is generally highly expressed in EwS, these data suggested that suppression of its transcription by EWSR1FLI1 is associated with embryonic processes that may be linked with poor patient outcome. To test this possibility, we generated two EwS cell lines (SK-N-MC, TC-71) with a DOX-inducible re-expression of $T C F 7 L 1$. These cell lines were chosen for functional analyses since they exhibited the lowest expression of TCF7L1 across the 5 EwS cell lines tested (Supplementary Fig. 1a). As shown in Fig. 2c, addition of DOX to the culture medium induced a 5.5-12.8-fold 
bioRxiv preprint doi: https://doi.org/10.1101/2021.02.25.432862; this version posted February $25,2021$. The copyright holder for this preprint (which was not certified by peer review) is the author/funder, who has granted bioRxiv a license to display the preprint in perpetuity. It is made available under aCC-BY-NC-ND 4.0 International license.

Cidre-Aranaz et al.

TCF7L1 inhibits metastasis in Ewing sarcoma

re-expression of TCF7L1. Consistent with the hypothesis that TCF7L1 may be a repressed EWSR1-ETS downstream transcription factor, transcriptome profiling of two EwS cell lines after either knockdown of EWSR1-ETS or re-expression of TCF7L1 showed a highly significant $\left(P=2.57 \times 10^{-165}\right.$ or $\left.P=5.34 \times 10^{-272}\right)$ overlap of concordantly DEGs (Supplementary Fig. 1c).

In agreement with this notion, conditional re-expression of TCF7L1 was accompanied by a significant reduction of cell proliferation in both cell lines (Fig. 2d). Such an effect was not observed in both cell lines transduced with a DOX-inducible empty vector (Supplementary Fig. 2a). Moreover, long-term re-expression of $T C F 7 L 1$ significantly inhibited the capacity for clonogenic growth in two-dimensional (2D) cultures, but not in control cells (Supplementary Figs. 2b,c). Since stemness is a key feature enabling anchorage-independent and threedimensional (3D) growth ${ }^{32,33}$, we tested whether TCF7L1 re-expression affects spheroidal growth of EwS cells when seeded in soft-agar. As displayed in Fig. 2e, re-expression of TCF7L1 significantly impaired anchorage-independent 3D growth of both EwS cell lines -an effect not observed in empty control cells (Supplementary Fig. 2d). Similar to these in vitro assays, conditional re-expression of $T C F 7 L 1$ impaired local tumor growth in a pre-clinical xenotransplantation mouse model using subcutaneous injections of tumor cells (Fig. 2f). Immunohistochemical (IHC) evaluation of the extracted tumors using an antibody against TCF7L1 showed specific re-expression of the protein in the DOX (+) group (Supplementary Fig. 2e,f). While these xenografts showed no difference in tumor necrosis in histological sections, we found a reduced mitotic index in tumors re-expressing TCF7L1 (Fig. 2g). Accordingly, tumors with high TCF7L1 expression showed a significant decrease of the proliferation marker Ki67 (Fig. 2h). Similar experiments performed with both cell lines transfected with empty control cells exhibited no significant differences in tumor growth, percentage of necrosis or mitotic index (Supplementary Figs. 2g-i). 
bioRxiv preprint doi: https://doi.org/10.1101/2021.02.25.432862; this version posted February $25,2021$. The copyright holder for this preprint (which was not certified by peer review) is the author/funder, who has granted bioRxiv a license to display the preprint in perpetuity. It is made available under aCC-BY-NC-ND 4.0 International license.

Cidre-Aranaz et al.

TCF7L1 inhibits metastasis in Ewing sarcoma

Taken together, these results indicated that EWSR1-ETS-meditated downregulation of TCF7L1 contributed to clonogenic and anchorage-independent growth as well as tumorgenicity of EwS cells.

\section{High TCF7L1 expression inhibits metastasis in EwS}

Since stemness features, such as elevated clonogenic capacity and anchorage-independent growth, are essential for circulating tumor cells to colonize and to develop into clinically apparent metastases in distant organs, we reasoned that $T C F 7 L 1$ may be linked to the metastatic process in EwS. In line with this notion, transcriptome profiling, subsequent gene-set enrichment and WGCNA of SK-N-MC and TC-71 EwS cells with/without conditional reexpression of this gene uncovered that low TCF7L1 levels led to overrepresentation of genesets involved in cellular migration (Fig. 3a). To validate this prediction, we first carried out transwell migration assays with our conditional TCF7L1 re-expression models. Indeed, as shown in Fig. 3b, re-expression of TCF7L1 significantly reduced cell migration through a porous membrane in vitro. In accordance, TCF7L1 re-expression significantly inhibited invasion and single-cell 3D migration of both cell lines in fibrin gel using an advanced microfluidic chamber (Fig. 3c). Next, we employed an orthotopic spontaneous in vivo metastasis model, in which we injected SK-N-MC EwS cells with/without conditional reexpression of TCF7L1 into the proximal tibiae of immunocompromised NOD/Scid/gamma (NSG) mice. Once signs of limping on the injected legs were observed, mice were sacrificed and legs as well as inner organs were histologically processed and evaluated for local tumor growth and evidence of macro- and micrometastasis. Excitingly, while there was no significant difference in local tumor growth in the limited space of the tibial plateau (Supplementary Fig. 3a,b), we observed a remarkable inhibition of macrometastatic spread to liver, lungs, and kidneys upon re-expression of $T C F 7 L 1$ (Fig. 3d). In fact, while $73 \%$ of organs across mice in the DOX (-) group showed evidence of metastasis to these organs, the percentage of organs 
bioRxiv preprint doi: https://doi.org/10.1101/2021.02.25.432862; this version posted February $25,2021$. The copyright holder for this preprint (which was not certified by peer review) is the author/funder, who has granted bioRxiv a license to display the preprint in perpetuity. It is made available under aCC-BY-NC-ND 4.0 International license.

Cidre-Aranaz et al.

TCF7L1 inhibits metastasis in Ewing sarcoma

with macrometastases dropped to 33\% upon DOX-induced $T C F 7 L 1$ re-expression (Fig. 3d). In addition, we noted a significantly reduced micrometastatic burden in the same organs upon histological evaluation (Fig. 3e). Similar results were obtained with TC-71 cells (Supplementary Fig. 3c-e).

In sum, these in vitro and in vivo results highlight TCF7L1 as an inhibitor of stemness and metastasis features in EwS.

\section{TCF7L1 role in EwS is mediated by its DNA binding domain}

To further investigate the mechanism of action of TCF7L1, we generated two EwS cell lines with conditional re-expression of different TCF7L1 deletion mutants for each of its major domains (high mobility group, HMG, which is the DNA binding domain; and $\beta$-catenin binding domain, CTNNB) and subjected them to functional assays. In a first step, we tested both mutants for their phenotype in clonogenic growth assays. As depicted in Fig. 4a, mutants harboring a deletion of the DNA-binding domain $(\triangle \mathrm{HMG})$ exhibited a normal clonogenic growth capacity of TC-71 and SK-N-MC cells. However, deletion of the CTNNB domain did not show such effect (Fig. 4a). These data suggested that the HMG domain is required for the inhibitory effect of TCF7L1 regarding clonogenic growth. Thus, in a second step, we tested the effect of the HMG domain for the migratory and tumorigenic phenotype of both cell lines. Strikingly, in both cell lines, deletion of the DNA binding domain completely abrogated the inhibitory effect of TCF7L1 on migration and tumor growth in vitro and in vivo, respectively (Figs. 4b,c). Taken together, these data demonstrate that DNA-binding of TCF7L1 is required to suppress the tumorigenic and migratory phenotype of EwS cells. 
bioRxiv preprint doi: https://doi.org/10.1101/2021.02.25.432862; this version posted February $25,2021$. The copyright holder for this preprint (which was not certified by peer review) is the author/funder, who has granted bioRxiv a license to display the preprint in perpetuity. It is made available under aCC-BY-NC-ND 4.0 International license.

Cidre-Aranaz et al.

TCF7L1 inhibits metastasis in Ewing sarcoma

\section{DISCUSSION}

In the present study, we harnessed a systems-biology approach to discover TCF7L1 as a key inhibitor of stemness and metastasis in EwS that is transcriptionally suppressed by EWSR1ETS, which sheds new light on the underlying mechanisms of metastasis in this highly aggressive malignancy. Traditionally, TCF7L1 has been described to play controversial roles in stemness/cell differentiation: on the one hand it can inhibit embryonic stem cell self-renewal through repression of pluripotency $\mathrm{TFs}^{34,35}$; while on the other hand, TCF7L1 can limit the differentiation of cutaneous stem cells ${ }^{36}$. In cancer, the role of $T C F 7 L 1$ remains poorly understood, and appears to be cell-type specific. For example, TCF7L1 expression has been linked to promotion of cell proliferation and tumor growth and an increase of sphere formation in breast cancer ${ }^{25}$, colorectal cancer ${ }^{26}$ and skin squamous cell carcinoma ${ }^{28}$. In contrast, it has been shown that ectopic expression of TCF7L1 inhibits self-renewal of liver cancer stem cells ${ }^{24}$, which are believed to play a prominent role in tumor relapse and metastasis ${ }^{37}$, thus highlighting a potential role of TCF7L1 in the stemness-metastasis axis that strongly depends on the cellular context. Interestingly, though TCF7L1 has been described as a Wnt signaling $\mathrm{TF}^{21}$, in our models the CCNB1-binding domain of TCF7L1 proved to be dispensable for its inhibitory effects on clonogenic growth and migratory capacities of EwS cells, suggesting that the mechanisms that govern TCF7L1 signaling are more complex than previously anticipated.

Our comparative transcriptome analyses of EwS primary tumors and TCF7L1 re-expression cell line models both highlighted an involvement of this protein in regulation of genes that collectively appear to suppress the locomotive and metastatic behavior of EwS cells. In line with this finding, low TCF7L1 expression was associated with poor patient outcome. This is particularly interesting in light of the recently proposed concept that undulating expression levels of EWSR1-FLI1 lead to a gradual switch from a more sessile and proliferative toward a more motile but less proliferative phenotype upon (transient) downregulation of the fusion oncogene $^{38,39}$. In contrast to this binary model of EWSR1-FLI1 $1^{\text {-high }}$ promoting proliferation and 
bioRxiv preprint doi: https://doi.org/10.1101/2021.02.25.432862; this version posted February $25,2021$. The copyright holder for this preprint (which was not certified by peer review) is the author/funder, who has granted bioRxiv a license to display the preprint in perpetuity. It is made available under aCC-BY-NC-ND 4.0 International license.

Cidre-Aranaz et al.

TCF7L1 inhibits metastasis in Ewing sarcoma

EWSR1-FLI1 ${ }^{\text {-low }}$ promoting metastasis, which - to the best of our knowledge - has so far only been based on non-orthotopic, pre-clinical and cell culture-based models and has not been proven clinically, our findings support a more complex regulation of stemness and metastasis in EwS. While the previous model follows a traditional epithelial-mesenchymal-transition (EMT) concept, our findings are rather in support of a more integrative concept of the 'migratory stem cell' ${ }^{19}$. In fact, our model suggests that EwS cells may reside in a 'metastable' state in which all EwS cells of a given EwS tumor are equipped simultaneously with both proliferative and migratory capacities that are not mutually exclusive ${ }^{18}$, but which may underlie a certain degree of accentuation upon different intrinsic or extrinsic cues of which EWSR1FLI1 may be one, but not the only important component. In line with this, the notion of a clearly defined subpopulation of cancer stem cells existing universally in all cancer types has been debated in favor of a plasticity model, where more fluid, bidirectional transitions are possible. These phenotypic reversals of cancer cells at different stages of cancer progression or under different contexts has been observed in several solid tumors including melanoma, non-small cell lung cancer and glioma ${ }^{40-43}$. Hence, a broader view on the underlying biological mechanism of metastasis is required to fully capture this complex process in EwS. In addition, our study highlights the power of a systems biology approach to identify critical genes that would have escaped detectability by sequencing approaches, and may serve as a blueprint for similar applications in other oligomutated (pediatric) cancers. 
bioRxiv preprint doi: https://doi.org/10.1101/2021.02.25.432862; this version posted February $25,2021$. The copyright holder for this preprint (which was not certified by peer review) is the author/funder, who has granted bioRxiv a license to display the preprint in perpetuity. It is made available under aCC-BY-NC-ND 4.0 International license.

Cidre-Aranaz et al.

TCF7L1 inhibits metastasis in Ewing sarcoma

\section{MATERIAL AND METHODS}

\section{Provenience of cell lines and cell culture conditions}

Human EwS cell lines and other cell lines were provided by the following repositories and/or sources: SK-N-MC, TC-71, MHH-ES1, and RD-ES cells were provided by the German Collection of Microorganism and Cell Cultures (DSMZ). A673 and HEK293T were purchased from American Type Culture Collection (ATCC). TC106 cells were kindly provided by the Children's Oncology Group (COG). A673/TR/shEF1 cells were kindly provided by J. Alonso (Madrid) $^{44}$.All cell lines were cultured in RPMI 1640 medium with stable glutamine (Biochrom, Germany) supplemented with 10\% tetracycline-free fetal bovine serum (Sigma-Aldrich, Germany), $100 \mathrm{U} / \mathrm{ml}$ penicillin and $100 \mu \mathrm{g} / \mathrm{ml}$ streptomycin (Merck, Germany) at $37{ }^{\circ} \mathrm{C}$ with $5 \% \mathrm{CO}_{2}$ in a humidified atmosphere. Cell lines were routinely tested for mycoplasma contamination by nested PCR, and cell line identity was regularly verified by STR-profiling.

RNA extraction, reverse transcription, and quantitative real-time polymerase chain reaction (qRT-PCR)

Total RNA was isolated using the NucleoSpin RNA kit (Macherey-Nagel, Germany). $1 \mu \mathrm{g}$ of total RNA was reverse-transcribed using High-Capacity cDNA Reverse Transcription Kit (Applied Biosystems, USA). qRT-PCR reactions were performed using SYBR green Mastermix (Applied Biosystems) mixed with diluted cDNA (1:10) and $0.5 \mu \mathrm{M}$ forward and reverse primer (total reaction volume $15 \mu \mathrm{l}$ ) on a BioRad CFX Connect instrument and analyzed using BioRad CFX Manager 3.1 software. Gene expression values were calculated using the $2^{-(\Delta \Delta \mathrm{Ct})}$ method $^{45}$ relative to the housekeeping gene $R P L P 0$ as internal control. The thermal conditions for qRT-PCR were as follows: heat activation at $95{ }^{\circ} \mathrm{C}$ for $2 \mathrm{~min}$, DNA denaturation at $95{ }^{\circ} \mathrm{C}$ for $10 \mathrm{sec}$, and annealing and elongation at $60{ }^{\circ} \mathrm{C}$ for $20 \mathrm{sec}(50 \mathrm{cycles})$, final denaturation at $95{ }^{\circ} \mathrm{C}$ for $30 \mathrm{sec}$. Oligonucleotides were purchased from MWG Eurofins Genomics (Germany) and are listed here: 
bioRxiv preprint doi: https://doi.org/10.1101/2021.02.25.432862; this version posted February 25,2021 . The copyright holder for this preprint (which was not certified by peer review) is the author/funder, who has granted bioRxiv a license to display the preprint in perpetuity. It is made available under aCC-BY-NC-ND 4.0 International license.

Cidre-Aranaz et al.

TCF7L1 inhibits metastasis in Ewing sarcoma

RPLP0 forward: 5'-GAAACTCTGCATTCTCGCTTC-3'

RPLPO reverse: 5'-GGTGTAATCCGTCTCCACAG-3'

TCF7L1 forward: 5'-ATGAACGCCTCGATGTCC-3'

TCF7L1 reverse: 5'-GGTTCCTGCTTGACGATGG-3'

EWSR 1-FLII forward: 5'-GCCAAGCTCCAAGTCAATATAGC-3“

EWSR1-FLII reverse: 5'-GAGGCCAGAATTCATGTTATTGC-3“

\section{TCF7L1 overexpression experiments}

To re-express TCF7L1 at physiological levels, we assessed the baseline expression levels of TCF7L1 in $18 \mathrm{EwS}$ cell lines for which whole-transcriptome data from Affymetrix Clariom D arrays was available (triplicates per cell line). As suitable models, we chose SK-N-MC and TC71 cells as they exhibited the lowest baseline TCF7L1 expression among these cell lines and proceeded with cloning as described in ${ }^{46}$. Briefly, full-length cDNA of TCF7L1 (NM_031283) was PCR-amplified from a commercial plasmid (Origene, SC126274) and an HA-tag was added by using AgeI- and NotI-restriction site containing primers (forward: 5'ATTAACCGGTGCCACCATGCCCCAGCTCG-3'; revers: 5'TAATGCGGCCGCTTAAGCGTAATCTGGAACATCGTAGTGGGCAGACTTGGTGACC $-3^{\prime}$ ) and a final $\mathrm{Tm}$ of $65^{\circ} \mathrm{C}$ (Phusion Polymerase, ThermoFisher), before cloning it into the multiple cloning site of a modified pTP vector ${ }^{47}$. TCF7L1 non-functional mutants were cloned from the same TCF7L1 (NM_031283) ORF cDNA clone using touchdown-PCR. The HAtagged CTNNB1-binding site truncated mutant was generated by using a different forward primer (5'-ATTAACCGGTGCCACCATGAACCAGAGCAGCAGCT-3') and a final Tm of $63{ }^{\circ} \mathrm{C}$. The HMG-Box binding site was deleted by fusing two PCR products (Product 1, final $\operatorname{Tm} 57^{\circ} \mathrm{C}$ ): forward: 5'-ATTAACCGGTGCCACCATGCCCCAGCTCG-3'; reverse: 5'CTTACCATAGTTGTCGGGCTTCTTTTCCTCCT-3'; Product 2 (final Tm $64{ }^{\circ} \mathrm{C}$ ): forward: 5'-GAGGAAAAGAAGCCCGACAACTATGGTAAGAAAAAGAAGAGGA-3'; reverse: 5'- 
bioRxiv preprint doi: https://doi.org/10.1101/2021.02.25.432862; this version posted February 25,2021 . The copyright holder for this preprint (which was not certified by peer review) is the author/funder, who has granted bioRxiv a license to display the preprint in perpetuity. It is made available under aCC-BY-NC-ND 4.0 International license.

Cidre-Aranaz et al.

TCF7L1 inhibits metastasis in Ewing sarcoma

TAATGCGGCCGCTTAAGCGTAATCTGGAACATCGTAGTGGGCAGACTTGGTGACC

-3') using an overhang-extension PCR protocol (overhang-extension PCR (final Tm $65{ }^{\circ} \mathrm{C}$ ):

forward: 5'-ATTAACCGGTGCCACCATGCCCCAGCTCG-3'; reverse: 5'TAATGCGGCCGCTTAAGCGTAATCTGGAACATCGTAGTGGGCAGACTTGGTGACC -3'). The generated inserts were double restriction-digested with AgeI and NotI (NEB) and ligated into the pTP backbone ${ }^{47}$ using T4 ligase (NEB). Positive clones were identified by colony PCR and cultured in $100 \mathrm{ml}$ of LB Broth containing $100 \mu \mathrm{g} / \mathrm{ml}$ Ampicillin. Plasmids were extracted and purified using a Midi-Prep Kit (Macherey-Nagel). The correct insertion of full-length $T C F 7 L 1$ cDNA, empty control or $T C F 7 L 1$-deficient mutants was verified by Sanger sequencing (sequencing primers: forward 5'-ACGTATGTCGAGGTAGGCGT-3'; reverse 5'TTCGTCTGACGTGGCAGC-3'). Lentiviral particles were generated in HEK293T cells and used for transduction of SK-N-MC and TC-71 EwS cells using polybrene $(8 \mu \mathrm{g} / \mathrm{ml})$. Transduced cells were selected with $0.5 \mu \mathrm{g} / \mathrm{ml}$ puromycin. Re-expression of TCF7L1 in SK-NMC and TC-71 cells was achieved by addition of $1 \mu \mathrm{g} / \mathrm{ml}$ DOX to the culture medium. Cells were single-cell cloned and specific clones were selected and tested for re-expression of TCF7L1. Only the clones exhibiting re-expression levels similar to the expression FCs after EWSR1-FLI1 silencing (see above) were selected for functional assays. Cells transfected with the empty vector were used as additional controls.

\section{Transcriptome analyses}

To assess the potential effect of TCF7L1 on gene expression in EwS cells, microarray analysis was performed. To this end, $1.2 \times 10^{4}$ cells per well were seeded in 6 -well plates and treated with $1 \mu \mathrm{g} / \mu \mathrm{l}$ DOX for $72 \mathrm{~h}$ (DOX-refreshment after $48 \mathrm{~h}$ ). Thereafter, total RNA was extracted with the ReliaPrep miRNA Cell and Tissue Miniprep System (Promega) and RNA quality was assessed with a Bioanalyzer. All samples had an RNA integrity number (RIN) $>9$ and were hybridized to Human Affymetrix Clariom D microarrays. Gene expression data were quantile 
bioRxiv preprint doi: https://doi.org/10.1101/2021.02.25.432862; this version posted February $25,2021$. The copyright holder for this preprint (which was not certified by peer review) is the author/funder, who has granted bioRxiv a license to display the preprint in perpetuity. It is made available under aCC-BY-NC-ND 4.0 International license.

Cidre-Aranaz et al.

TCF7L1 inhibits metastasis in Ewing sarcoma

normalized with Transcriptome Analysis Console (v4.0; Thermo Fisher Scientific) using the SST-RMA algorithm as previously described ${ }^{48}$. Annotation of the data was performed using the Affymetrix library for Clariom D Array (version 2, Homo sapiens) on gene level. DEGs with consistent and significant FCs across cell lines were identified as follows: Normalized gene expression signals were $\log 2$ transformed. To avoid false discovery artifacts due to the detection of only minimally expressed genes, we excluded all genes with a lower expression value than that observed for $E R G$ of the respective cell lines (log2 expression signal of 7.08 for SK-N-MC and 6.57 for TC-71), which is known to be virtually not expressed in EWSR1-FLI1 positive EwS cell lines ${ }^{15}$. The FCs of the control samples (empty vector) and both TCF7L1 reexpressing EwS cell lines were calculated for each cell line separately. Then the FCs in the TCF7L1 re-expressing samples were normalized to that of the empty control cells. Then both FCs were averaged to obtain the mean FC per gene across cell lines. DEGs were determined as having a $\log 2 \mathrm{FC}>0.5$ or $<-0.5$, respectively.

\section{Gene-set enrichment analysis (GSEA)}

To identify enriched gene-sets, genes were ranked by their expression FC between the groups DOX (-) and DOX (+). GSEA was performed using the FGSEA R package (v 3.6.3) based on Gene Ontology (GO) biological processes terms from MSigDB (c5.all.v7.0.symbols.gmt) ${ }^{49}$. GO terms were filtered for statistical significance (adjusted $P<0.05$ ) and a normalized enrichment score $|(\mathrm{NES})|>2(10,000$ permutations). In order to construct a network, the Weighted Gene Correlation Network Analysis R package (WGCNA R) ${ }^{31}$ was used. Briefly, a binary matrix of GO-terms $\times$ genes (where 1 indicates the gene is present in the GO term and 0 indicates it is not) was created. Then, the Jaccard's distance for all possible pairs was computed to create a symmetric GO adjacent matrix. Clusters of similar GO terms were identified using dynamicTreeCut algorithm, and the top $20 \%$ highest edges were selected for visualization. The highest scoring node in each cluster was determined as the cluster label 
bioRxiv preprint doi: https://doi.org/10.1101/2021.02.25.432862; this version posted February $25,2021$. The copyright holder for this preprint (which was not certified by peer review) is the author/funder, who has granted bioRxiv a license to display the preprint in perpetuity. It is made available under aCC-BY-NC-ND 4.0 International license.

Cidre-Aranaz et al.

TCF7L1 inhibits metastasis in Ewing sarcoma

(rName). The obtained network and nodes files were fed into Cytoscape (v 3.8.0) for network design and visualization as previously described ${ }^{50}$.

\section{Correlation analysis}

To identify gene-sets correlated with $T C F 7 L 1$ expression in primary tumors, we created a preranked list of genes ordered by Pearson's correlation coefficient with TCF7L1 based on transcriptomic data of 166 of $\mathrm{EwS}^{23}$ and GSEA was performed as described above.

\section{Proliferation assays}

For proliferation assays, $5-8 \times 10^{5}$ EwS cells per well (depending on the cell line) were seeded in triplicates per group in 6-well plates and treated with $1 \mu \mathrm{g} / \mathrm{ml} \mathrm{DOX}$ for $72 \mathrm{~h}$. Thereafter, cells including their supernatant were harvested and counted using standardized hemocytometers (CChip, Biochrom) and the Trypan-Blue (Sigma-Aldrich) exclusion method as described in ${ }^{51}$.

\section{Clonogenic growth assays}

For clonogenic growth assays, $T C F 7 L 1$ re-expressing EwS cells and respective controls were seeded in triplicates at low density $\left(2 \times 10^{3}\right.$ cells $)$ per well in 12-well plates and grown for 9-11 days (depending on the cell line) with/without DOX-treatment (renewal of DOX or vehicle every $48 \mathrm{~h}$ ). Thereafter, colonies were stained with crystal violet (Sigma-Aldrich) and colony numbers and areas were measured with the ImageJ Plugin Colony area. The clonogenicity index was calculated by multiplying the counted colonies with the corresponding colony area.

\section{Sphere formation assays in soft agar}

For the analysis of anchorage-independent growth, TCF7L1 re-expressing EwS cells and respective controls were pre-treated with/without DOX for $48 \mathrm{~h}$ before seeding. A base of $2 \mathrm{ml}$ of agar 1:1 with 2× DMEM medium was poured in wells of 6-well plates and left for 30-60 
bioRxiv preprint doi: https://doi.org/10.1101/2021.02.25.432862; this version posted February $25,2021$. The copyright holder for this preprint (which was not certified by peer review) is the author/funder, who has granted bioRxiv a license to display the preprint in perpetuity. It is made available under aCC-BY-NC-ND 4.0 International license.

Cidre-Aranaz et al.

TCF7L1 inhibits metastasis in Ewing sarcoma

min to solidify. Then, $5 \times 10^{3}$ cells per well were seeded in $500 \mu 1$ in triplicates per condition (/+DOX). Cells were kept in culture for 9-11 days and new medium (-/+DOX) was added on top of each well every $48 \mathrm{~h}$. Spheres were stained with $50 \mu \mathrm{l}$ of a $5 \mathrm{mg} / \mathrm{ml}$ MTT solution that was added dropwise to each well and incubated for $1 \mathrm{~h}$. Pictures of the stained spheres were taken and their area was analyzed with ImageJ.

\section{Transwell assays}

For the analysis of migration through a porous membrane we proceeded as described $\mathrm{in}^{52}$. Briefly, TCF7L1 re-expressing EwS cells, their mutants, and respective controls were pretreated with/without DOX for $72 \mathrm{~h}$ before seeding and were starved by decreasing FCS concentration in the growth medium to $0.5 \%$ during the last $24 \mathrm{~h}$. The following morning, fresh medium with $10 \%$ FCS (chemoattractant) was plated in the lower compartment of a 24 -well plate. Transwell attachments were placed on top and $1 \times 10^{5}$ cells were plated on them with medium containing $0.5 \% \mathrm{FCS}$ with/without DOX. Cells were allowed to migrate for $6 \mathrm{~h}$. After that, transwell inserts were washed with PBS and the top membrane was cleaned of remaining unmigrated cells with a cotton swab. Migrated cells were fixed with a $4 \%$ formaldehyde solution and stained with crystal violet. Transwells were washed with water to eliminate excess crystal violet and migrated cells were de-stained with a solution containing $2 \%$ acetic acid in PBS during 10 minutes on a shaker. The obtained solution was measured by absorbance at 570 $\mathrm{nm}$ in a plate reader.

\section{Microfluidic invasion and single cell 3D migration assay}

TC-71 and SK-N-MC TCF7L1 re-expressing EwS cells were pre-treated for 48h with DOX $(1 \mu \mathrm{g} / \mathrm{ml})$. Then, $1.5 \times 10^{6}$ cells $/ \mathrm{ml}$ were embedded in a $2.5 \mathrm{mg} / \mathrm{ml}$ fibrin matrix and introduced in the central channel of a microfluidic device as described ${ }^{53}$. Following fibrin polymerization (20 min inside a humidity chamber), culture medium was added to the side channels of the 
bioRxiv preprint doi: https://doi.org/10.1101/2021.02.25.432862; this version posted February $25,2021$. The copyright holder for this preprint (which was not certified by peer review) is the author/funder, who has granted bioRxiv a license to display the preprint in perpetuity. It is made available under aCC-BY-NC-ND 4.0 International license.

Cidre-Aranaz et al.

TCF7L1 inhibits metastasis in Ewing sarcoma

microfluidic device. The next day, medium was substituted with $\mathrm{CO}_{2}$ independent culture medium (Thermo Fisher) and cells were imaged with an automated wide-field epifluorescence microscope (Lionheart FX, BioTek Instruments, Inc., Winooski, VT, USA). Images of at least 5 regions of interest for each microfluidic device per condition $(n=3)$ were captured every 30 min for $15 \mathrm{~h}$. Temporal stacks were reconstructed using ImageJ and single cell 3D movement inside the fibrin matrix was quantified employing the image processing software Imaris (v.9.1, Bitplane AG, Zurich, Switzerland).

\section{In vivo experiments in mice}

$3 \times 10^{6}$ SK-N-MC or TC-71 EwS cells harboring a re-expression construct for either TCF7L1, the TCF7L1 deletion mutant (TCF7L1-HMGmut) or empty controls were injected in a 1:1 mix of cells suspended in PBS with Geltrex Basement Membrane Mix (ThermoFisher) in the right flank of 10-12 weeks old NOD/scid/gamma (NSG) mice as described in $^{54}$. Tumor diameters were measured every second day with a caliper and tumor volume was calculated by the formula $\mathrm{L} \times 1^{2} / 2$, where $\mathrm{L}$ is the length and 1 the width. When the tumors reached an average volume of $80 \mathrm{~mm}^{3}$, mice were randomized in two groups of which one was henceforth treated with $2 \mathrm{mg} / \mathrm{ml}$ DOX (Beladox, Bela-pharm, Germany) dissolved in drinking water containing $5 \%$ sucrose (Sigma-Aldrich) to induce an in vivo re-expression (DOX $(+)$ ), whereas the other group only received 5\% sucrose (control, DOX (-)). Once tumors of control groups reached an average volume of $1,500 \mathrm{~mm}^{3}$, all mice of the experiment were sacrificed by cervical dislocation. Other humane endpoints were determined as follows: Ulcerated tumors, loss of $20 \%$ body weight, constant curved or crouched body posture, bloody diarrhea or rectal prolapse, abnormal breathing, severe dehydration, visible abdominal distention, obese Body Condition Scores (BCS), apathy, and self-isolation. For analysis of EwS growth in bone, EwS cells were orthotopically injected into the proximal tibial plateau of NSG mice. To this end, one day before injection, mice were pre-treated with $800 \mathrm{mg} / \mathrm{kg}$ mouse weight/day Metamizol in drinking 
bioRxiv preprint doi: https://doi.org/10.1101/2021.02.25.432862; this version posted February $25,2021$. The copyright holder for this preprint (which was not certified by peer review) is the author/funder, who has granted bioRxiv a license to display the preprint in perpetuity. It is made available under aCC-BY-NC-ND 4.0 International license.

Cidre-Aranaz et al.

TCF7L1 inhibits metastasis in Ewing sarcoma

water as analgesia. On the day of injection, mice were anesthetized with inhaled isoflurane (1.5$2.5 \%$ in volume) and their eyes were protected with Bepanthen eye cream. After disinfection of the injection site, $2 \times 10^{5}$ cells $/ 20 \mu 1$ were directly injected with a fine $28 \mathrm{G}$ needle (Hamilton, USA) into the right proximal tibia. For durable pain prophylaxis until the first day after intraosseous injection, mice were subsequently treated with Metamizole in drinking water (800 $\mathrm{mg} / \mathrm{kg}$ mouse weight/day). At the first day after injection of tumor cells, mice were randomized in two groups of which one received henceforth $2 \mathrm{mg} / \mathrm{ml}$ DOX (BelaDox, Bela-pharm) dissolved in drinking water containing 5\% sucrose (Sigma-Aldrich) to induce TCF7L1 reexpression $(\mathrm{DOX}(+))$, whereas the other group only received 5\% sucrose (control, DOX (-)). All tumor-bearing mice were sacrificed by cervical dislocation at the predefined experimental endpoint, when the mice reached a humane endpoint as listed above or exhibited signs of limping at the injected leg (event). After extraction of the tumors, a small fraction of each tumor was snap frozen in liquid nitrogen to preserve the RNA isolation, while the remaining tumor tissue was fixed in $4 \%$-formalin and embedded in paraffin for immunohistology. In the case of the orthotopic model, all inner organs were harvested, weighed, photographed, 4\%-formalinfixed and embedded in paraffin for (immuno)histology. For analysis of the extent of metastatic spread, HE-stained histological slides were evaluated for presence of EwS cells and the area of metastasis versus total area was calculated. Animal experiments were approved by the governments of Upper Bavaria and Northbaden and conducted in accordance with ARRIVE guidelines, recommendations of the European Community (86/609/EEC), and United Kingdom Coordinating Committee on Cancer Research (UKCCCR) guidelines for the welfare and use of animals in cancer research.

\section{Immunohistochemistry (IHC) and immunoreactivity scoring (IRS)}

For IHC, 4- $\mu \mathrm{m}$ sections were cut and antigen retrieval was carried out by heat treatment with Target Retrieval Solution (S1699, Agilent Technologies) for Ki67, or Tris buffer pH 9.0 for 
bioRxiv preprint doi: https://doi.org/10.1101/2021.02.25.432862; this version posted February $25,2021$. The copyright holder for this preprint (which was not certified by peer review) is the author/funder, who has granted bioRxiv a license to display the preprint in perpetuity. It is made available under aCC-BY-NC-ND 4.0 International license.

Cidre-Aranaz et al.

TCF7L1 inhibits metastasis in Ewing sarcoma

TCF7L1 staining, respectively. For Ki67, the slides were stained with monoclonal anti-Ki67 raised in rabbit (1:200, 275R-15, Cell Marque/Sigma-Aldrich) for $60 \mathrm{~min}$ at RT, followed by a monoclonal secondary horseradish peroxidase (HRP)-coupled horse-anti-rabbit antibody (ImmPRESS Reagent Kit, MP-7401, Vector Laboratories). AEC-Plus (K3469, Agilent Technologies) was used as chromogen. For TCF7L1, the slides were stained with polyclonal anti-TCF7L1 antibody raised in rabbit (1:100 for complete slides, 1:25 for TMAs; 28835 clone D15G11 lot 5, Cell Signaling). For TMA analysis, DAKO REAL Detection System, Alkaline Phosphatase/RED Rabbit/Mouse was used (K5005, Dako). For xenograft slides, Biotin-SPconjugated AffiniPure Goat Anti-Rabbit IgG (H+L) (111-065-144, Jackson Immunoresearch) and Alkaline Phosphatase Streptavidin (SA-5100, Vector) were used. The chromogen used was that included in the DAKO REAL Detection System (K 5005, Dako). Samples were counterstained with hematoxylin (H-3401, Vector Laboratories; or T865.3, Mayer, Roth). FFPE xenografts of the EwS cell lines were stained with HE for mitosis counting and metastatic spread assessment. Slides were scanned on a Nanozoomer-SQ Digital Slide Scanner (Hamamatsu Photonics K.K.) and visualized using NDP.view2 image viewing software (Hamamatsu Photonics K.K.). Mitoses were quantified by a blinded observer per high-power field $(40 \times)$. Final scores/quantifications were determined by examination of 5-10 high-power fields of at least one section per sample. Evaluation of immunoreactivity of TCF7L1 was carried out in analogy to scoring of hormone receptors with a modified Immune Reactive Score (IRS) ranging from 0-12 that was adapted to EwS tumors ${ }^{55,56}$. Briefly, the percentage of cells with expression of the given antigen was scored and classified in five grades (grade $0=0-19 \%$, grade $1=20-39 \%$, grade $2=40-59 \%$, grade $3=60-79 \%$ and grade $4=80-100 \%$ ). In addition, the intensity of marker immunoreactivity was determined (grade $0=$ none, grade $1=$ low, grade $2=$ moderate and grade $3=$ strong). The product of these two grades defined the final IRS. Slides were scored by $n \geq 2$ independent observers. 
bioRxiv preprint doi: https://doi.org/10.1101/2021.02.25.432862; this version posted February $25,2021$. The copyright holder for this preprint (which was not certified by peer review) is the author/funder, who has granted bioRxiv a license to display the preprint in perpetuity. It is made available under aCC-BY-NC-ND 4.0 International license.

Cidre-Aranaz et al.

TCF7L1 inhibits metastasis in Ewing sarcoma

\section{Survival analysis}

Kaplan-Meier survival analyses were carried out in 166 EwS patients whose molecularly confirmed and retrospectively collected primary tumors were profiled at the mRNA level by gene expression microarrays in previous studies ${ }^{57-60}$. To that end, microarray data generated on Affymetrix HG-U133Plus2.0, Affymetrix HuEx-1.0-st or Amersham/GE Healthcare CodeLink microarrays of the 166 EwS tumors (Gene Expression Omnibus (GEO) accession codes: $\underline{\text { GSE63157 }}^{57}, \underline{\text { GSE12102 }}{ }^{58}, \underline{\text { GSE17618 }}{ }^{59}, \underline{\text { GSE34620 }}^{60}$ provided with clinical annotations were normalized separately as previously described ${ }^{55}$. Only genes that were represented on all microarray platforms were kept for further analysis. Batch effects were removed using the ComBat algorithm ${ }^{61}$. Data processing was done in $\mathrm{R}$.

\section{Statistical analysis and software}

Statistical data analysis was performed using PRISM 9 (GraphPad Software Inc., Ca, USA) on the raw data. If not specified otherwise in the figure legends, comparison of two groups in functional in vitro experiments was carried out using a two-sided Mann-Whitney test. If not specified otherwise in the figure legends, data are presented as dot plots with horizontal bars representing means and whiskers representing the standard error of the mean (SEM). Sample size for all in vitro experiments were chosen empirically. For in vivo experiments, the sample size was predetermined using power calculations with $\beta=0.8$ and $\alpha<0.05$ based on preliminary data and in compliance with the 3R principles (replacement, reduction, refinement). In KaplanMeier survival analyses, curves were calculated from all individual survival times of mice, respectively. Statistical differences between the groups were assessed by a Mantel-Haenszel test. 
bioRxiv preprint doi: https://doi.org/10.1101/2021.02.25.432862; this version posted February 25, 2021. The copyright holder for this

preprint (which was not certified by peer review) is the author/funder, who has granted bioRxiv a license to display the preprint in perpetuity. It is made available under aCC-BY-NC-ND 4.0 International license.

Cidre-Aranaz et al.

TCF7L1 inhibits metastasis in Ewing sarcoma

\section{Data availability}

Original microarray data that support the findings of this study were deposited at the National

Center for Biotechnology Information (NCBI) GEO and are accessible through the accession number GSE165929. 
bioRxiv preprint doi: https://doi.org/10.1101/2021.02.25.432862; this version posted February $25,2021$. The copyright holder for this preprint (which was not certified by peer review) is the author/funder, who has granted bioRxiv a license to display the preprint in perpetuity. It is made available under aCC-BY-NC-ND 4.0 International license.

Cidre-Aranaz et al.

TCF7L1 inhibits metastasis in Ewing sarcoma

\section{REFERENCES}

1. Wong, D. J. et al. Module map of stem cell genes guides creation of epithelial cancer stem cells. Cell Stem Cell 2, 333-344 (2008).

2. Batlle, E. \& Clevers, H. Cancer stem cells revisited. Nat. Med. 23, 1124-1134 (2017).

3. Martincorena, I. \& Campbell, P. J. Somatic mutation in cancer and normal cells. Science 349, 1483-1489 (2015).

4. Varela, I. et al. Exome sequencing identifies frequent mutation of the SWI/SNF complex gene PBRM1 in renal carcinoma. Nature 469, 539-542 (2011).

5. Lawrence, M. S. et al. Mutational heterogeneity in cancer and the search for new cancerassociated genes. Nature 499, 214-218 (2013).

6. Grünewald, T. G. P. et al. Ewing sarcoma. Nat. Rev. Dis. Primer 4, 5 (2018).

7. Thiel, U. et al. No improvement of survival with reduced- versus high-intensity conditioning for allogeneic stem cell transplants in Ewing tumor patients. Ann. Oncol. Off. J. Eur. Soc. Med. Oncol. 22, 1614-1621 (2011).

8. Gröbner, S. N. et al. The landscape of genomic alterations across childhood cancers. Nature 555, 321-327 (2018).

9. Delattre, O. et al. Gene fusion with an ETS DNA-binding domain caused by chromosome translocation in human tumours. Nature 359, 162-165 (1992).

10. Sorensen, P. H. et al. A second Ewing's sarcoma translocation, $\mathrm{t}(21 ; 22)$, fuses the EWS gene to another ETS-family transcription factor, ERG. Nat. Genet. 6, 146-151 (1994).

11. Richter, G. H. S. et al. EZH2 is a mediator of EWS/FLI1 driven tumor growth and metastasis blocking endothelial and neuro-ectodermal differentiation. Proc. Natl. Acad. Sci. U. S. A. 106, 5324-5329 (2009).

12. Tirode, F. et al. Mesenchymal stem cell features of Ewing tumors. Cancer Cell 11, 421429 (2007).

13. Riggi, N. et al. EWS-FLI-1 modulates miRNA145 and SOX2 expression to initiate mesenchymal stem cell reprogramming toward Ewing sarcoma cancer stem cells. Genes Dev. 24, 916-932 (2010).

14. Tirode, F. et al. Genomic landscape of Ewing sarcoma defines an aggressive subtype with co-association of STAG2 and TP53 mutations. Cancer Discov. 4, 1342-1353 (2014).

15. Crompton, B. D. et al. The genomic landscape of pediatric Ewing sarcoma. Cancer Discov. 4, 1326-1341 (2014).

16. Brohl, A. S. et al. The genomic landscape of the Ewing Sarcoma family of tumors reveals recurrent STAG2 mutation. PLoS Genet. 10, e1004475 (2014).

17. Visvader, J. E. \& Lindeman, G. J. Cancer stem cells: current status and evolving complexities. Cell Stem Cell 10, 717-728 (2012).

18. Sannino, G., Marchetto, A., Kirchner, T. \& Grünewald, T. G. P. Epithelial-to-Mesenchymal and Mesenchymal-to-Epithelial Transition in Mesenchymal Tumors: A Paradox in Sarcomas? Cancer Res. 77, 4556-4561 (2017).

19. Brabletz, T., Jung, A., Spaderna, S., Hlubek, F. \& Kirchner, T. Opinion: migrating cancer stem cells - an integrated concept of malignant tumour progression. Nat. Rev. Cancer 5, 744-749 (2005). 
bioRxiv preprint doi: https://doi.org/10.1101/2021.02.25.432862; this version posted February $25,2021$. The copyright holder for this preprint (which was not certified by peer review) is the author/funder, who has granted bioRxiv a license to display the preprint in perpetuity. It is made available under aCC-BY-NC-ND 4.0 International license.

Cidre-Aranaz et al.

TCF7L1 inhibits metastasis in Ewing sarcoma

20. Grünewald, T. G. et al. Sarcoma treatment in the era of molecular medicine. EMBO Mol. Med. e11131 (2020) doi:10.15252/emmm.201911131.

21. Sokol, S. Y. Maintaining embryonic stem cell pluripotency with Wnt signaling. Dev. Camb. Engl. 138, 4341-4350 (2011).

22. Warde-Farley, D. et al. The GeneMANIA prediction server: biological network integration for gene prioritization and predicting gene function. Nucleic Acids Res. 38, W214-220 (2010).

23. Musa, J. et al. Cooperation of cancer drivers with regulatory germline variants shapes clinical outcomes. Nat. Commun. 10, 4128 (2019).

24. Shan, J. et al. Tcf711 Acts as a Suppressor for the Self-Renewal of Liver Cancer Stem Cells and Is Regulated by IGF/MEK/ERK Signaling Independent of $\beta$-Catenin. Stem Cells Dayt. Ohio 37, 1389-1400 (2019).

25. Slyper, M. et al. Control of breast cancer growth and initiation by the stem cell-associated transcription factor TCF3. Cancer Res. 72, 5613-5624 (2012).

26. Murphy, M., Chatterjee, S. S., Jain, S., Katari, M. \& DasGupta, R. TCF7L1 Modulates Colorectal Cancer Growth by Inhibiting Expression of the Tumor-Suppressor Gene EPHB3. Sci. Rep. 6, 28299 (2016).

27. Eshelman, M. A., Shah, M., Raup-Konsavage, W. M., Rennoll, S. A. \& Yochum, G. S. TCF7L1 recruits CtBP and HDAC1 to repress DICKKOPF4 gene expression in human colorectal cancer cells. Biochem. Biophys. Res. Commun. 487, 716-722 (2017).

28. $\mathrm{Ku}, \mathrm{A}$. T. et al. TCF7L1 promotes skin tumorigenesis independently of $\beta$-catenin through induction of LCN2. eLife 6, (2017).

29. Barretina, J. et al. The Cancer Cell Line Encyclopedia enables predictive modelling of anticancer drug sensitivity. Nature 483, 603-607 (2012).

30. Baldauf, M. C. et al. Systematic identification of cancer-specific MHC-binding peptides with RAVEN. Oncoimmunology 7, e1481558 (2018).

31. Langfelder, P. \& Horvath, S. WGCNA: an R package for weighted correlation network analysis. BMC Bioinformatics 9, 559 (2008).

32. Mori, S. et al. Anchorage-independent cell growth signature identifies tumors with metastatic potential. Oncogene 28, 2796-2805 (2009).

33. Elia, I. et al. Proline metabolism supports metastasis formation and could be inhibited to selectively target metastasizing cancer cells. Nat. Commun. 8, 15267 (2017).

34. Yi, F. et al. Opposing effects of Tcf3 and Tcf1 control Wnt stimulation of embryonic stem cell self-renewal. Nat. Cell Biol. 13, 762-770 (2011).

35. Atlasi, Y. et al. Wnt signaling regulates the lineage differentiation potential of mouse embryonic stem cells through Tcf3 down-regulation. PLoS Genet. 9, e1003424 (2013).

36. Nguyen, H. et al. Tcf3 and Tcf4 are essential for long-term homeostasis of skin epithelia. Nat. Genet. 41, 1068-1075 (2009).

37. Magee, J. A., Piskounova, E. \& Morrison, S. J. Cancer stem cells: impact, heterogeneity, and uncertainty. Cancer Cell 21, 283-296 (2012).

38. Chaturvedi, A., Hoffman, L. M., Welm, A. L., Lessnick, S. L. \& Beckerle, M. C. The EWS/FLI Oncogene Drives Changes in Cellular Morphology, Adhesion, and Migration in Ewing Sarcoma. Genes Cancer 3, 102-116 (2012). 
bioRxiv preprint doi: https://doi.org/10.1101/2021.02.25.432862; this version posted February $25,2021$. The copyright holder for this preprint (which was not certified by peer review) is the author/funder, who has granted bioRxiv a license to display the preprint in perpetuity. It is made available under aCC-BY-NC-ND 4.0 International license.

Cidre-Aranaz et al.

TCF7L1 inhibits metastasis in Ewing sarcoma

39. Franzetti, G.-A. et al. Cell-to-cell heterogeneity of EWSR1-FLI1 activity determines proliferation/migration choices in Ewing sarcoma cells. Oncogene 36, 3505-3514 (2017).

40. Chaffer, C. L. et al. Normal and neoplastic nonstem cells can spontaneously convert to a stem-like state. Proc. Natl. Acad. Sci. 108, 7950-7955 (2011).

41. Quintana, E. et al. Phenotypic heterogeneity among tumorigenic melanoma cells from patients that is reversible and not hierarchically organized. Cancer Cell 18, 510-523 (2010).

42. Sharma, S. V. et al. A chromatin-mediated reversible drug tolerant state in cancer cell subpopulations. Cell 141, 69-80 (2010).

43. Charles, N. et al. Perivascular nitric oxide activates notch signaling and promotes stem-like character in PDGF-induced glioma cells. Cell Stem Cell 6, 141-152 (2010).

44. Carrillo, J. et al. Cholecystokinin down-regulation by RNA interference impairs Ewing tumor growth. Clin. Cancer Res. Off. J. Am. Assoc. Cancer Res. 13, 2429-2440 (2007).

45. Livak, K. J. \& Schmittgen, T. D. Analysis of relative gene expression data using real-time quantitative PCR and the 2(-Delta Delta C(T)) Method. Methods San Diego Calif 25, 402408 (2001).

46. Knott, M. M. L. \& Cidre-Aranaz, F. Ewing Sarcoma-Specific (Re)expression Models. Methods Mol. Biol. Clifton NJ 2226, 119-138 (2021).

47. Bauernfeind, F. et al. NLRP3 inflammasome activity is negatively controlled by miR-223. J. Immunol. Baltim. Md 1950 189, 4175-4181 (2012).

48. Marchetto, A. et al. Oncogenic hijacking of a developmental transcription factor evokes vulnerability toward oxidative stress in Ewing sarcoma. Nat. Commun. 11, 2423 (2020).

49. Subramanian, A. et al. Gene set enrichment analysis: a knowledge-based approach for interpreting genome-wide expression profiles. Proc. Natl. Acad. Sci. U. S. A. 102, 1554515550 (2005).

50. Waszak, S. M. et al. Germline Elongator mutations in Sonic Hedgehog medulloblastoma. Nature 580, 396-401 (2020).

51. Funk, C. M. \& Musa, J. Proliferation Assessment by Trypan Blue Exclusion in Ewing Sarcoma. Methods Mol. Biol. Clifton NJ 2226, 151-158 (2021).

52. Cidre-Aranaz, F. Analysis of Migration and Invasion in Ewing Sarcoma. Methods Mol. Biol. Clifton NJ 2226, 167-179 (2021).

53. Bersini, S. et al. Nup93 regulates breast tumor growth by modulating cell proliferation and actin cytoskeleton remodeling. Life Sci. Alliance 3, (2020).

54. Cidre-Aranaz, F. \& Ohmura, S. Tumor Growth Analysis of Ewing Sarcoma Cell Lines Using Subcutaneous Xenografts in Mice. Methods Mol. Biol. Clifton NJ 2226, 191-199 (2021).

55. Baldauf, M. C. et al. Robust diagnosis of Ewing sarcoma by immunohistochemical detection of super-enhancer-driven EWSR1-ETS targets. Oncotarget 9, 1587-1601 (2018).

56. Orth, M. F. et al. High Specificity of BCL11B and GLG1 for EWSR1-FLI1 and EWSR1ERG Positive Ewing Sarcoma. Cancers 12, (2020).

57. Volchenboum, S. L. et al. Gene Expression Profiling of Ewing Sarcoma Tumors Reveals the Prognostic Importance of Tumor-Stromal Interactions: A Report from the Children's Oncology Group. J. Pathol. Clin. Res. 1, 83-94 (2015). 
bioRxiv preprint doi: https://doi.org/10.1101/2021.02.25.432862; this version posted February 25,2021 . The copyright holder for this preprint (which was not certified by peer review) is the author/funder, who has granted bioRxiv a license to display the preprint in perpetuity. It is made available under aCC-BY-NC-ND 4.0 International license.

Cidre-Aranaz et al.

TCF7L1 inhibits metastasis in Ewing sarcoma

58. Scotlandi, K. et al. Overcoming resistance to conventional drugs in Ewing sarcoma and identification of molecular predictors of outcome. J. Clin. Oncol. Off. J. Am. Soc. Clin. Oncol. 27, 2209-2216 (2009).

59. Savola, S. et al. High Expression of Complement Component 5 (C5) at Tumor Site Associates with Superior Survival in Ewing's Sarcoma Family of Tumour Patients. ISRN Oncol. 2011, 168712 (2011).

60. Postel-Vinay, S. et al. Common variants near TARDBP and EGR2 are associated with susceptibility to Ewing sarcoma. Nat. Genet. 44, 323-327 (2012).

61. Stein, C. K. et al. Removing batch effects from purified plasma cell gene expression microarrays with modified ComBat. BMC Bioinformatics 16, 63 (2015).

\section{ACKNOWLEDGEMENTS}

We thank Dr. Paul Northcott and Dr. Brian Gudenas for providing R scripts for weighted gene correlation network analyses and Carlos Rodriguez-Martin for assistance with script adaptation. We thank Anja Heier and Andrea Sendelhofert for expert technical assistance. This work was mainly supported by the Wilhelm Sander-Foundation (2016.167.1), the Barbara \& Hubertus Trettner Foundation, and the Dr. Rolf M. Schwiete Foundation. In addition, the laboratory of T.G.P.G. was supported by the Matthias-Lackas Foundation, the Dr. Leopold and Carmen Ellinger Foundation, the German Cancer Aid (DKH-70112257 and DKH-70114111), the Gert und Susanna Mayer Foundation, the SMARCB1 association, and the Barbara und Wilfried Mohr Foundation. J.L. was supported by a scholarship of the Chinese Scholarship Council (CSC), and M.K. and C.M.F. by scholarships from the German Cancer Aid. M.M. was supported by the Swiss National Science Foundation (SNF 310030_179167).

\section{AUTHOR CONTRIBUTIONS}

F.C.A, M.M.L.K., and T.G.P.G. conceived the study. F.C.A. and T.G.P.G wrote the paper, and drafted the figures and tables. F.C.A., M.M.L.K., and S. K. carried out in vitro experiments. F.C.A, M.F.O., and T.G.P.G. performed bioinformatic and statistical analyses. F.C.A, M.M.L.K., J.L., T.L.B.H., J.M, R.I., and A.B. performed and/or coordinated in vivo 
bioRxiv preprint doi: https://doi.org/10.1101/2021.02.25.432862; this version posted February $25,2021$. The copyright holder for this preprint (which was not certified by peer review) is the author/funder, who has granted bioRxiv a license to display the preprint in perpetuity. It is made available under aCC-BY-NC-ND 4.0 International license.

Cidre-Aranaz et al.

TCF7L1 inhibits metastasis in Ewing sarcoma

experiments. M.F.O., K.C., M.J.C.G., G.A., S.B., C.A., M.M., C.F., A.M., S.O., L.R.-P., and M.K. contributed to experimental procedures. T.K. and F.B. provided laboratory infrastructure and/or histological guidance. T.G.P.G. supervised the study and data analysis. All authors read and approved the final manuscript.

\section{COMPETING INTERESTS}

The authors declare no conflict of interest.

\section{FIGURE LEGENDS}

Fig. 1 | Application of a systems biology approach identifies TCF7L1 as a prognostically relevant EWSR1-ETS-regulated network hub

a) Workflow depicting a step-wise systems biology approach to identify DEGs regulated by EWSR1-ETS, involved in regulation of cell differentiation, functioning as highly interconnected TFs, and associated with overall survival in a cohort of 166 EwS patients. Number of genes represent remaining candidates after each filtering step. b) Network of EWSR1-ETS-regulated genes involved in regulation of cell differentiation. Genes are depicted as nodes (circles). Blue nodes represent TFs, node outline color show up- (green) or down(red) regulation by EWSR1-ETS. Node border width represent strength of regulation by EWSR1-ETS (the thicker the border the higher the fold-change). Black dots surrounding the nodes represent interconnections with other nodes within the network. Connecting lines show three types of interconnection: physical (red), pathway (blue), genetic (brown). Line width represents strength of interconnection. c) Close-up image of highly interconnected TFs located at the center of the network (blue nodes). d) Kaplan-Meier survival analysis of 166 primary EwS patients stratified by quintile TCF7L1 expression. Mantel-Haenszel test, Bonferroni corrected. DEG: differentially expressed genes; KD: knockdown. 
bioRxiv preprint doi: https://doi.org/10.1101/2021.02.25.432862; this version posted February $25,2021$. The copyright holder for this preprint (which was not certified by peer review) is the author/funder, who has granted bioRxiv a license to display the preprint in perpetuity. It is made available under aCC-BY-NC-ND 4.0 International license.

Cidre-Aranaz et al.

TCF7L1 inhibits metastasis in Ewing sarcoma

Fig. 2 | TCF7L1 re-expression inhibits tumorigenesis in vitro and in vivo

a) TCF7L1 expression levels of EwS and 17 additional tumor entities in cell lines (Cancer Cell Line Encyclopedia, CCLE) or primary tumors. Data are represented as bar plots where horizontal bars represent mean and SEM. The number of samples per group $(n)$ is given in parentheses. RMS, rhabdomyosarcoma; NSCLC, non-small cell lung carcinoma; SCLC: smallcell lung carcinoma. b) Weighted Gene Correlation Network Analysis (WGCNA) of enriched gene-sets obtained by Pearson correlation analysis of genes whose expression is negatively correlated with TCF7L1 expression in Affymetrix gene expression data of 166 primary EwS tumors. Network depicts signatures presenting NES $>1.5$ and $P<0,05$. NES, normalized enrichment score. c) Relative $T C F 7 L 1$ expression as measured by qRT-PCR of TC-71 and SKN-MC cells containing a DOX-inducible re-expression construct for TCF7L1. Cells were grown either with or without DOX for $72 \mathrm{~h} . n \geq 6$ biologically independent experiments. Twosided Mann-Whitney test. d) Viable cell count of TC-71 and SK-N-MC cells containing a DOX-inducible re-expression construct for $T C F 7 L 172 \mathrm{~h}$ after treatment with or without DOX. Data are mean and SEM, $n=7$ biologically independent experiments. Two-sided Mann-Whitney test. e) Relative percentage of area covered by colonies grown in soft-agar of TC-71 and SKN-MC cells containing a DOX-inducible re-expression construct for TCF7L1. Cells were grown either with or without DOX. $n=3$ biologically independent experiments. Two-sided Mann-Whitney test. f) Growth of EwS subcutaneous xenografts of TC-71 and SK-N-MC cells containing a DOX-inducible re-expression construct for TCF7L1 (arrow indicates start of DOX-treatment). Data are represented as means ( $n=7$ animals/group). Two-sided MannWhitney test. g) Ex vivo analysis of relative necrotic area (top) and mitotic index (bottom) of xenografted TC-71 and SK-N-MC cell lines. Data are mean and SEM, $n=7$ animals/group. h) Ex vivo analysis of Ki67 positivity of xenografted TC-71 and SK-N-MC cell lines. Horizontal bars represent means and whiskers SEM, $n=7$ animals/group. $P$-values were determined via $\chi^{2}$ 
bioRxiv preprint doi: https://doi.org/10.1101/2021.02.25.432862; this version posted February 25,2021 . The copyright holder for this preprint (which was not certified by peer review) is the author/funder, who has granted bioRxiv a license to display the preprint in perpetuity. It is made available under aCC-BY-NC-ND 4.0 International license.

Cidre-Aranaz et al.

TCF7L1 inhibits metastasis in Ewing sarcoma

test testing all positives (high and moderate immunoreactivity) versus negatives. Histological images depict representative Ki67 micrographs. Scale bar $=30 \mu \mathrm{m}$.

\section{Fig. 3 | High TCF7L1 expression inhibits metastasis in EwS}

a) Weighted Gene Correlation Network Analysis (WGCNA) depicting functional gene enrichment of down- or up-regulated genes in TCF7L1 re-expressing EwS cells. Network depicts signatures presenting $P<0,05$, NES $>2$. NES, normalized enrichment score. Arrows depict direction of gene regulation. b) Relative percentage of migrated cells in 6h. TC-71 and SK-N-MC EwS cells containing a DOX-inducible re-expression construct for TCF7L1 where pre-treated with or without DOX for $72 \mathrm{~h} . n \geq 7$ biologically independent experiments. Two-sided Mann-Whitney test. c) Invasion and single cell migrated distance in 15h. TC-71 and SK-N-MC EwS cells containing a DOX-inducible re-expression construct for $T C F 7 L 1$ where pre-treated with or without DOX for $72 \mathrm{~h}$ and added to a microfluidic chamber containing a fibrin compartment. $n \geq 3$ biologically independent experiments. Two-sided unpaired t-test. d) Schematic representation of the experimental design: TC-71 or SK-N-MC EwS cell lines containing a DOX-inducible re-expression construct for $T C F 7 L 1$ were injected in the right tibia plateau. Animals were subsequently randomized and treated with or without DOX. At the end of the experiment, mice were evaluated ex vivo for presence of spontaneous metastases in inner organs. Pie charts depict percentage of metastasis-free organs (blue) in each condition, $n$ represents total number of metastasis. Bottom pictures show representative images of metastatic organs in DOX (-) and DOX (+) conditions. $n=8$ animals/group. e) Graph depicts relative area of histological metastatic spread of orthotopically injected SK-N-MC EwS cells containing a DOX-inducible re-expression construct for TCF7L1. $n=21$ slides/group. Two-sided Mann Whitney test. Pictures show representative histological images of HE stainings from the evaluated organs. $20 \times$ magnification, scale bar is $50 \mu \mathrm{m}$. M, metastasis; N, normal tissue. 
bioRxiv preprint doi: https://doi.org/10.1101/2021.02.25.432862; this version posted February 25,2021 . The copyright holder for this preprint (which was not certified by peer review) is the author/funder, who has granted bioRxiv a license to display the preprint in perpetuity. It is made available under aCC-BY-NC-ND 4.0 International license.

Cidre-Aranaz et al.

TCF7L1 inhibits metastasis in Ewing sarcoma

Fig. 4 | TCF7L1 role in EwS is mediated by its DNA binding domain

a) Relative colony number of colony-forming assays (CFAs) of TC-71 (left) and SK-N-MC (right) cells containing a DOX-inducible re-expression construct for TCF7L1, empty control, or one of the two deletion mutants for TCF7L1 (deletion mutant for the $\beta$-catenin binding domain, $\triangle \mathrm{CTNNB}$; deletion mutant for the DNA binding domain, $\triangle \mathrm{HMG}$ ). Cells were grown either with or without DOX. $n=4$ biologically independent experiments. b) Relative percentage of migrated cells in 6h. TC-71 and SK-N-MC EwS cells containing a DOX-inducible reexpression construct for TCF7L1 DNA binding domain ( $\triangle \mathrm{HMG)}$ where pre-treated with or without DOX for $72 \mathrm{~h} . n \geq 8$ biologically independent experiments. c) Growth of EwS subcutaneous xenografts of TC-71 and SK-N-MC cells containing a DOX-inducible reexpression construct for TCF $7 L 1$ deletion mutant $\triangle \mathrm{HMG}$ (arrow indicates start of DOXtreatment). Data are represented as means ( $n=7$ animals/group). Two-sided Mann-Whitney test.

\section{LEGENDS TO SUPPLEMENTARY FIGURES}

\section{Supplementary Fig. 1 | TCF7L1 expression in EwS cell lines}

a) TCF7L1 and EWSR1-ETS expression in $5 \mathrm{EwS}$ cell lines with conditional knock-down (KD) of EWSR1-ETS for 72h measured by qRT-PCR. $n \geq 3$ biologically independent experiments. b) Left: EWSR1-FLI1 and TCF7L1 expression (Affymetrix microarrays) in A673/TR/shEF1 xenografts after $96 \mathrm{~h}$ of DOX treatment. Horizontal bars represent means, $n=3$ xenografts per group. Two-sided independent $t$-test. Right: representative IHC for (EWSR1-)FLI1 and TCF7L1. Scale bar $=20 \mu \mathrm{m}$. c) Size-proportional Venn diagrams of genes concordantly regulated by $96 \mathrm{~h}$ after knockdown of EWSR1-ETS or upregulation of TCF7L1 in TC-71 and SK-N-MC EwS cells. Minimum $\log _{2}$ fold-change \pm 0.5 . Fischer's exact test. 
bioRxiv preprint doi: https://doi.org/10.1101/2021.02.25.432862; this version posted February $25,2021$. The copyright holder for this preprint (which was not certified by peer review) is the author/funder, who has granted bioRxiv a license to display the preprint in perpetuity. It is made available under aCC-BY-NC-ND 4.0 International license.

Cidre-Aranaz et al.

TCF7L1 inhibits metastasis in Ewing sarcoma

\section{Supplementary Fig. 2 | TCF7L1 re-expression inhibits tumorigenesis in vitro and in vivo}

a) Viable cell count of TC-71 and SK-N-MC cells containing a DOX-inducible re-expression construct for an empty control $72 \mathrm{~h}$ after treatment with or without DOX. Data are mean and SEM, $n \geq 3$ biologically independent experiments. Two-sided Mann-Whitney test. b) Relative colony number of colony-forming assays (CFAs) of TC-71 and SK-N-MC cells containing a DOX-inducible re-expression construct for $T C F 7 L 1$. Cells were grown either with or without DOX. $n=4$ biologically independent experiments. Two-sided Mann-Whitney test. c) Relative colony number of CFAs of TC-71 and SK-N-MC cells containing a DOX-inducible reexpression construct for an empty control. Cells were grown either with or without DOX. $n=4$ biologically independent experiments. Two-sided Mann-Whitney test. d) Relative percentage of area covered by colonies grown in soft-agar of TC-71 and SK-N-MC cells containing a DOX-inducible re-expression construct for an empty control. Cells were grown either with or without DOX. $n=3$ biologically independent experiments. Two-sided Mann-Whitney test. e) Representative images of TCF7L1 expression on protein level by IHC on xenografted tissues from in vivo subcutaneous xenografts of TC-71 and SK-N-MC EwS cells with conditional reexpression of TCF7L1. f) Immuno Reactive Scores (IRS) of TCF7L1 expression in all subcutaneous xenografts of TC-71 and SK-N-MC EwS cells with conditional re-expression of TCF7L1 ( $n=7$ animals/group). Horizontal bars represent mean. g) Subcutaneous growth of EwS xenografts of TC-71 and SK-N-MC cells containing a DOX-inducible re-expression construct for an empty control (arrow indicates start of DOX-treatment). Data are represented as means ( $n=5$ animals/group). Two-sided Mann-Whitney test. h) Ex vivo analysis of mitotic index. Data are mean and SEM, $n \geq 4$ animals/group. i) Relative necrotic area of xenografted empty control TC-71 and SK-N-MC cell lines. Data are mean and SEM, $n \geq 4$ animals/group. 
bioRxiv preprint doi: https://doi.org/10.1101/2021.02.25.432862; this version posted February $25,2021$. The copyright holder for this preprint (which was not certified by peer review) is the author/funder, who has granted bioRxiv a license to display the preprint in perpetuity. It is made available under aCC-BY-NC-ND 4.0 International license.

Cidre-Aranaz et al.

TCF7L1 inhibits metastasis in Ewing sarcoma

\section{Supplementary Fig. 3 | High TCF7L1 expression inhibits metastasis in EwS}

a) Kaplan-Meier plots showing event-free survival time of NSG mice bearing orthotopic xenografts of SK-N-MC cells containing a DOX-inducible re-expression construct for TCF7L1. After intra-osseous injection, mice were randomized and treated with either vehicle (-) or DOX (+). Event: first signs of limping. Log-rank (Mantel-Cox) test b) Representative micrographs of HE from tibias obtained from both groups of mice orthotopically injected with SK-N-MC cells containing a DOX-inducible re-expression construct for TCF7L1. Mice were treated with either vehicle $(-)$ or DOX $(+)$. Scale bar $=500 \mu \mathrm{m}$. EwS infiltrating area is shown in blue dots, black dots show bone tissue, green lines show muscle tissue and black lines show cartilage tissue. c) Graph depicts total number of macro-metastases counted after inner organ extraction in mice bearing orthotopically implanted TC-71 cells containing a DOX-inducible reexpression construct for TCF 7L1. $n=8$ evaluated livers from independent animals in each group.

d) Representative images from metastatic organs of mice bearing orthotopically implanted TC71 cells containing a DOX-inducible re-expression construct for TCF7L1 in DOX (-) and DOX $(+)$ conditions. e) Representative histological images of HE stainings from the evaluated organs. $20 \times$ magnification, scale bar $=50 \mu \mathrm{m} . \mathrm{M}$, metastasis; $\mathrm{N}$, normal tissue. 
Figure 1 Cidre-Aranaz et al.

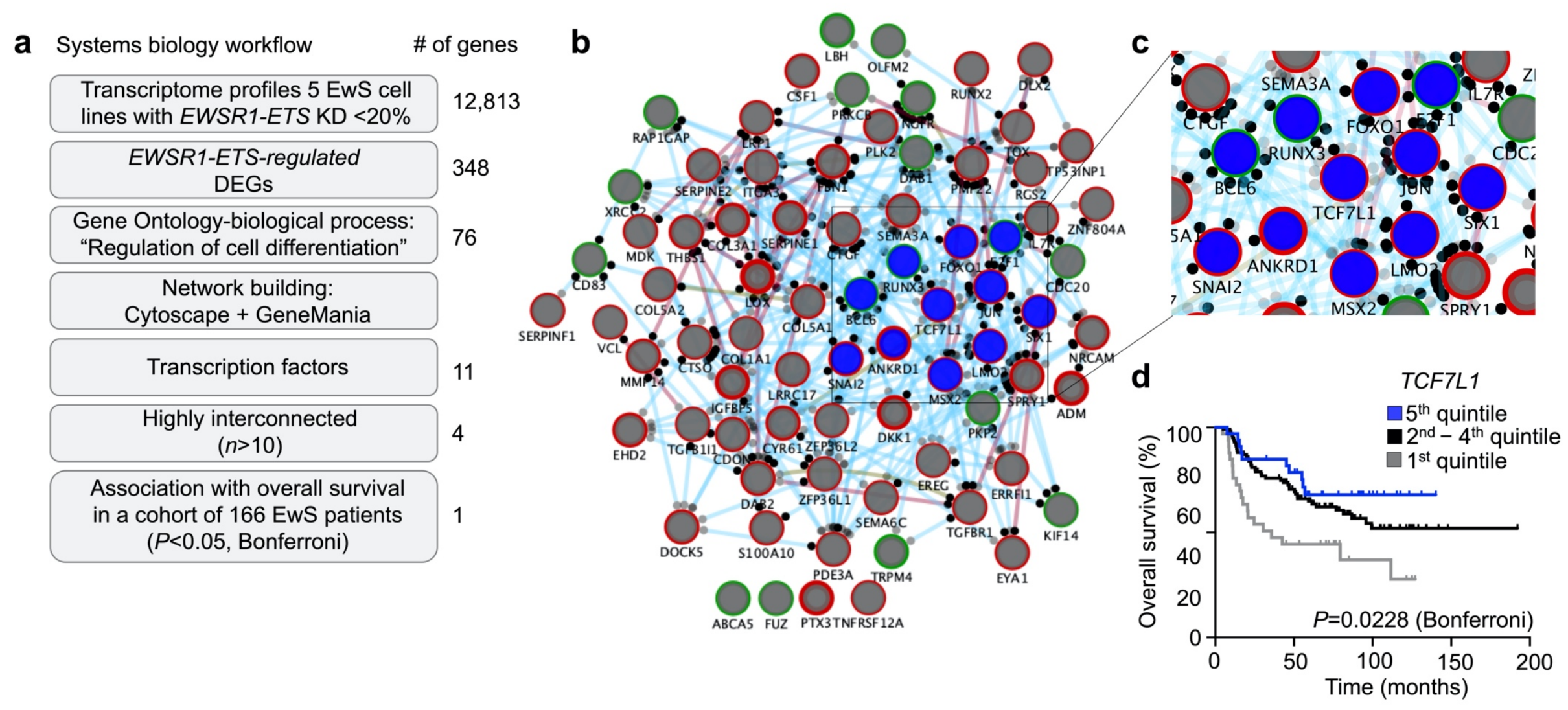




\section{Figure 2 Cidre-Aranaz et al.}

a

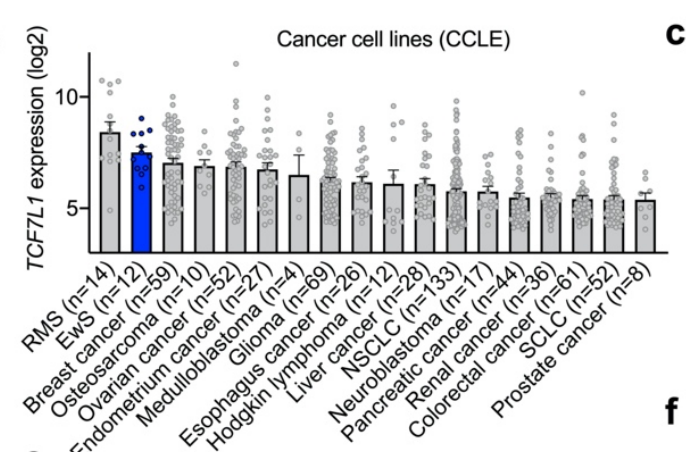

तु

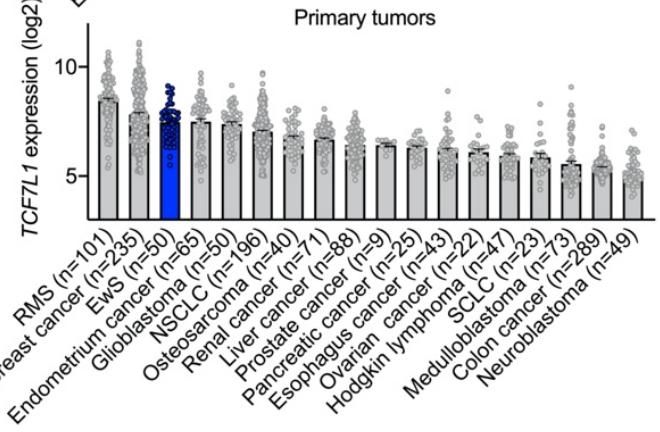

b TCF7L1-correlated signatures in 166 primary EwS

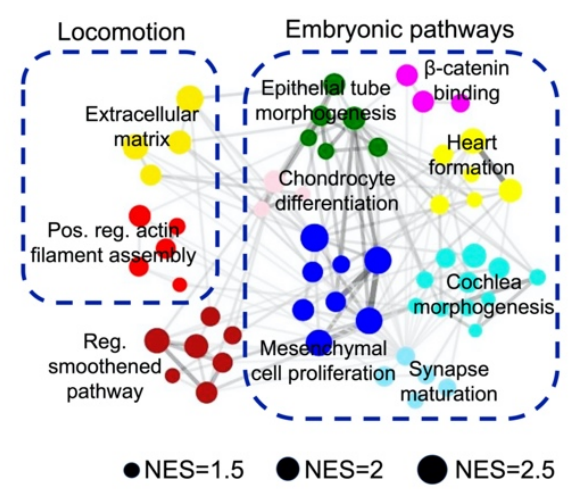

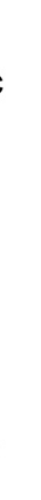
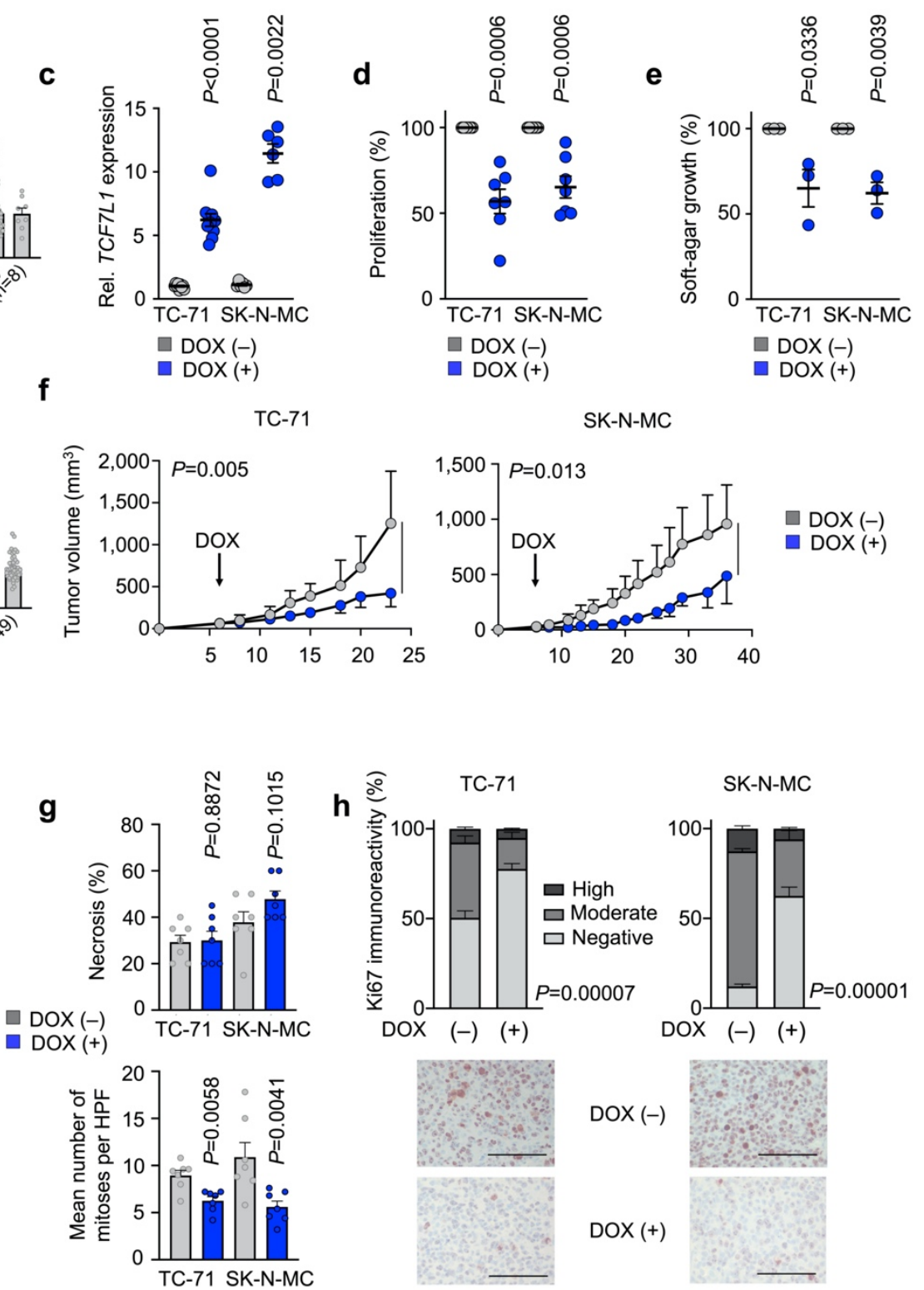

DOX $(-)$

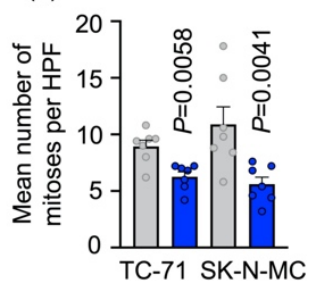

SK-N-MC

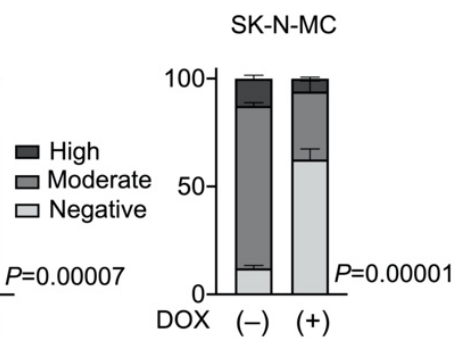

DOX (-)

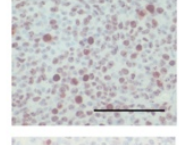

$\operatorname{DOX}(+)$ 
Figure 3 Cidre-Aranaz et al.

a

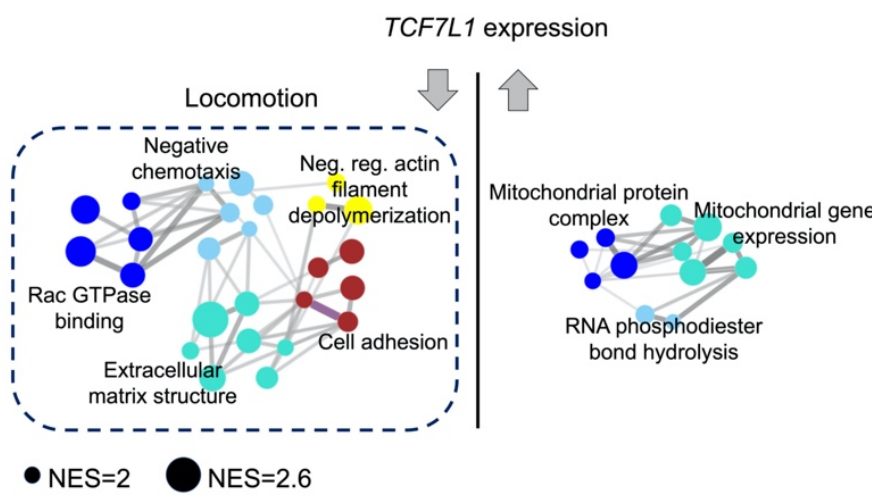

b

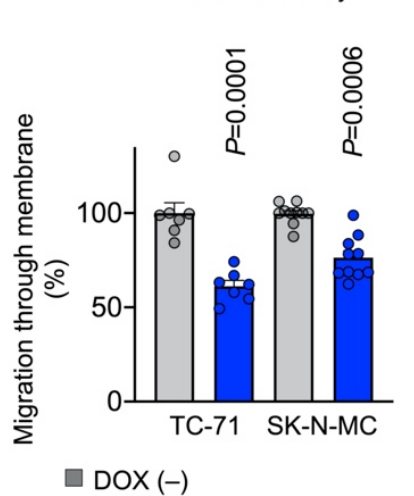

C Single-cell 3D tracing assay

$\square \operatorname{DOX}(-)$

e

d

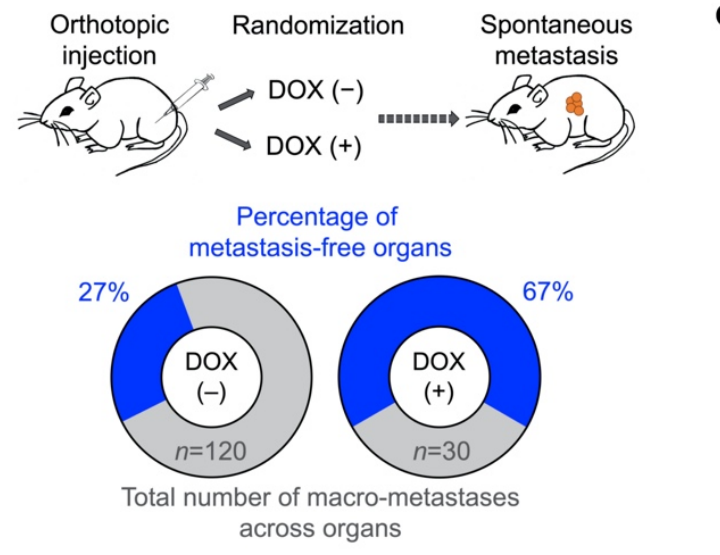

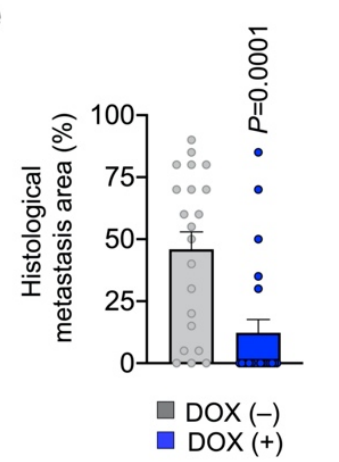
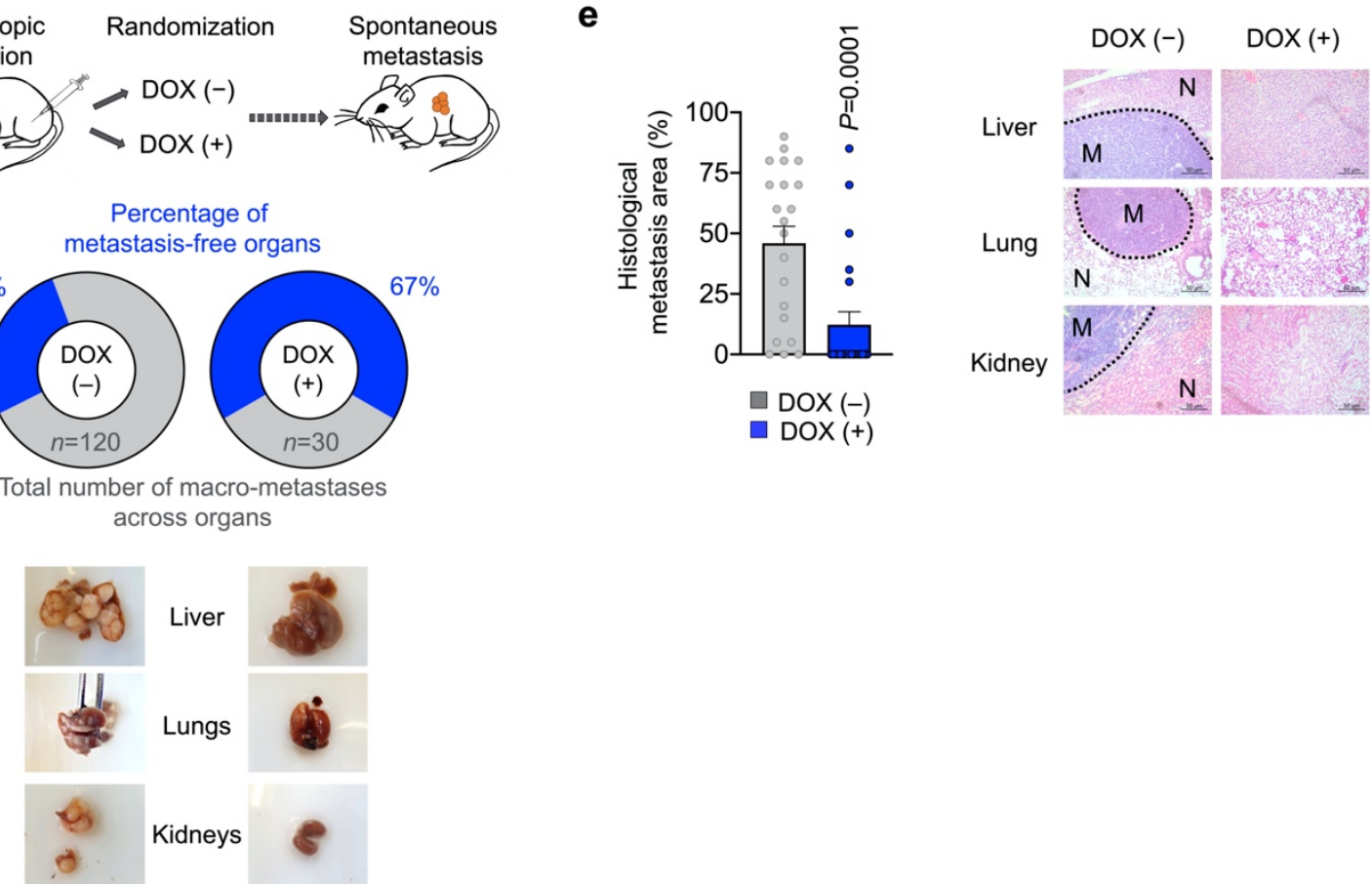
Figure 4 Cidre-Aranaz et al.

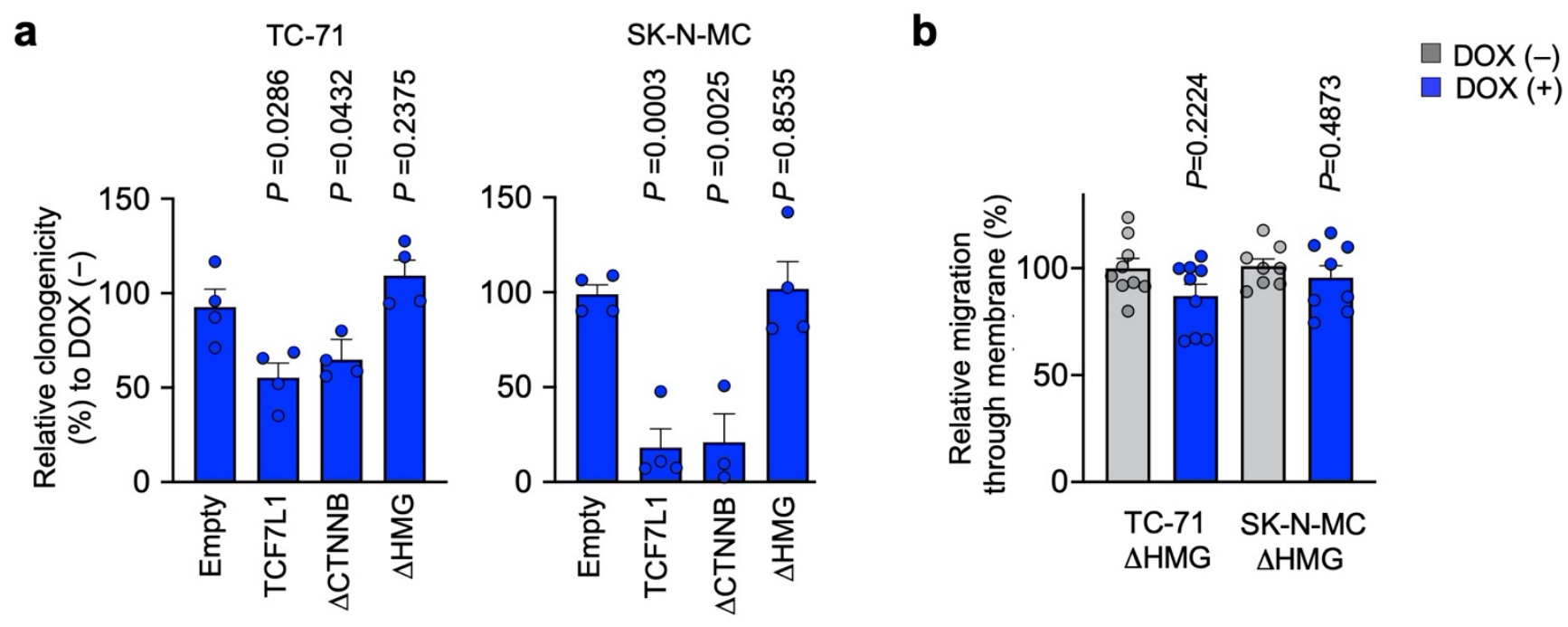

c

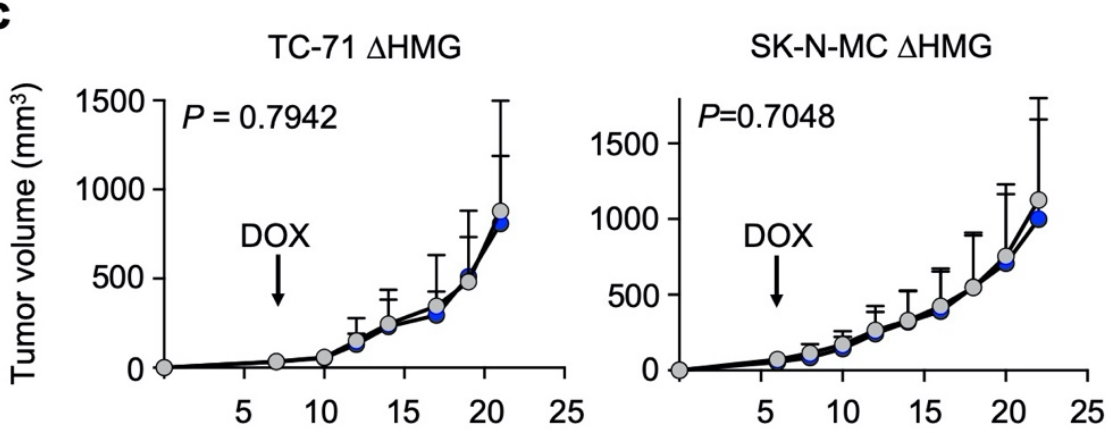




\section{Supp. Figure 1 Cidre-Aranaz et al.}

a

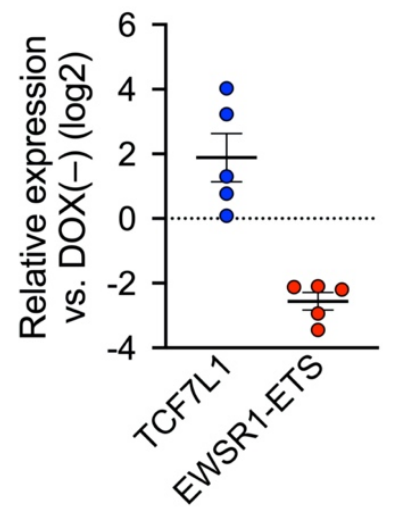

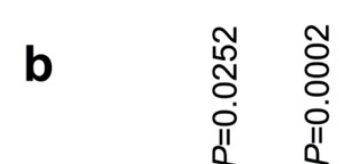

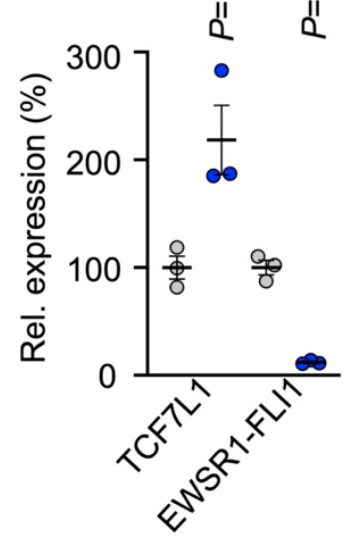

A673/TR/shEF1

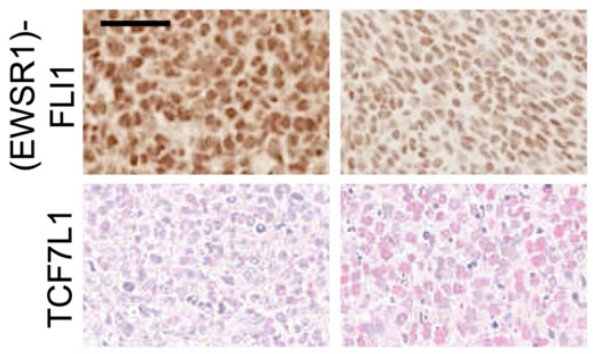

c

Overlap of concordantly regulated genes
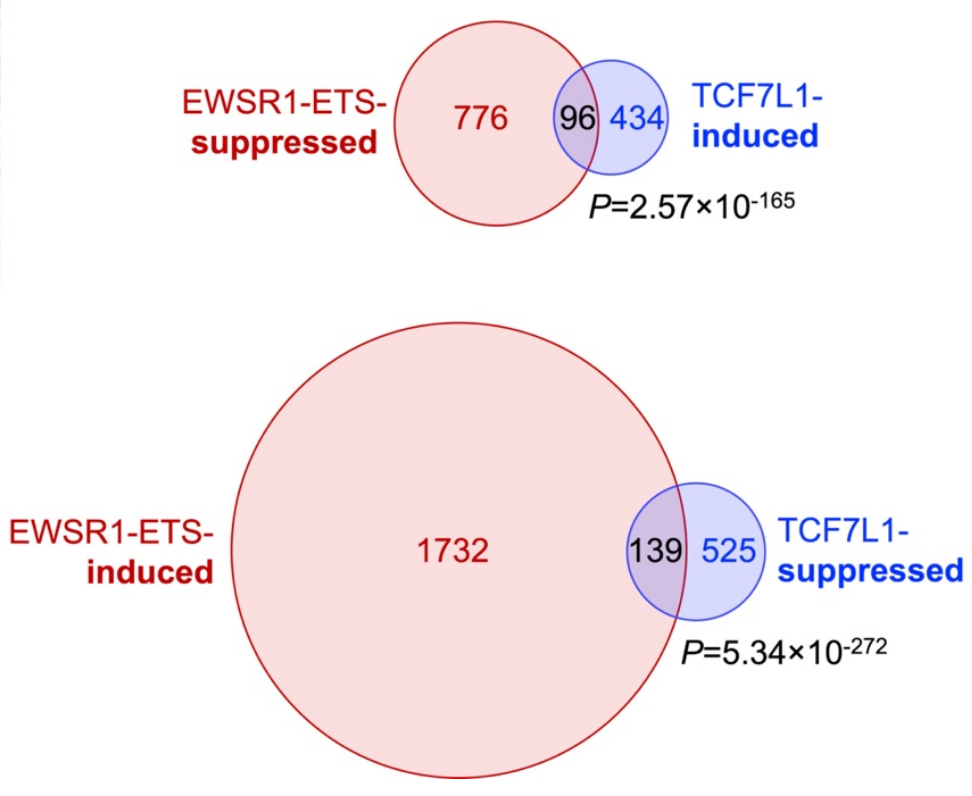
Supp. Figure 2 Cidre-Aranaz et al.
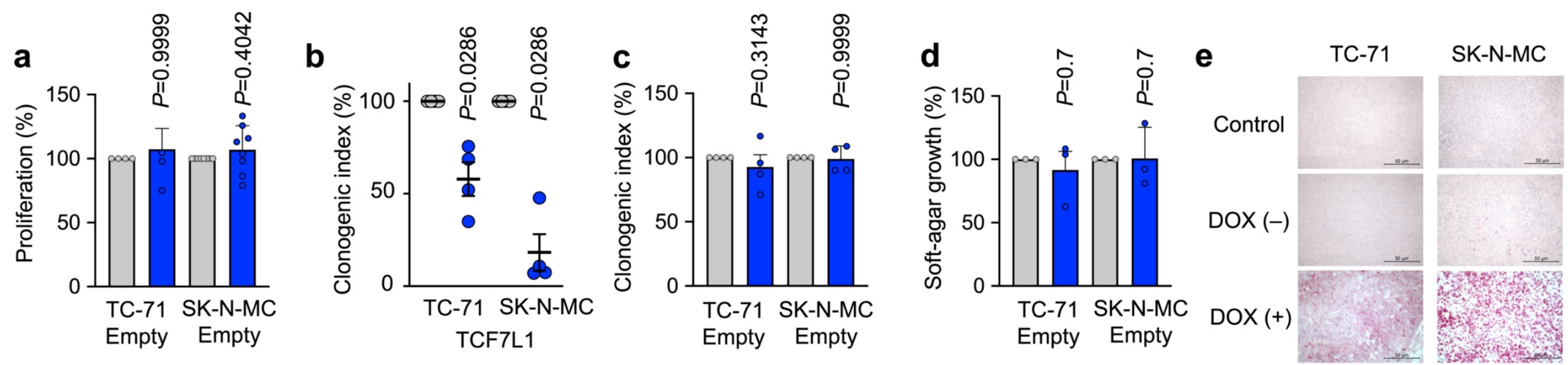

\section{$\square \operatorname{DOX}(-)$ \\ $\square \operatorname{DOX}(+)$}
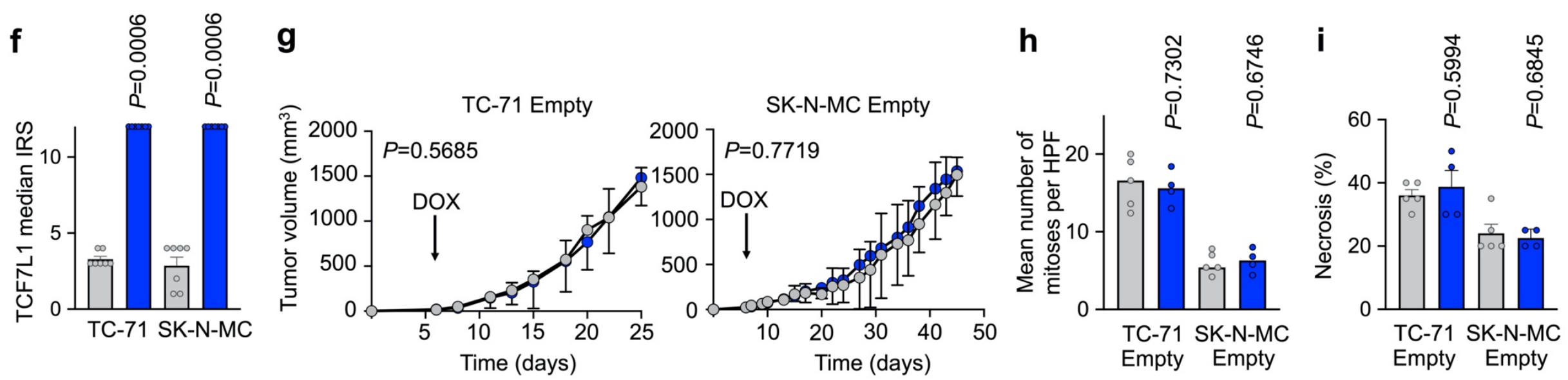


\section{Supp. Figure $3 \quad$ Cidre-Aranaz et al.}

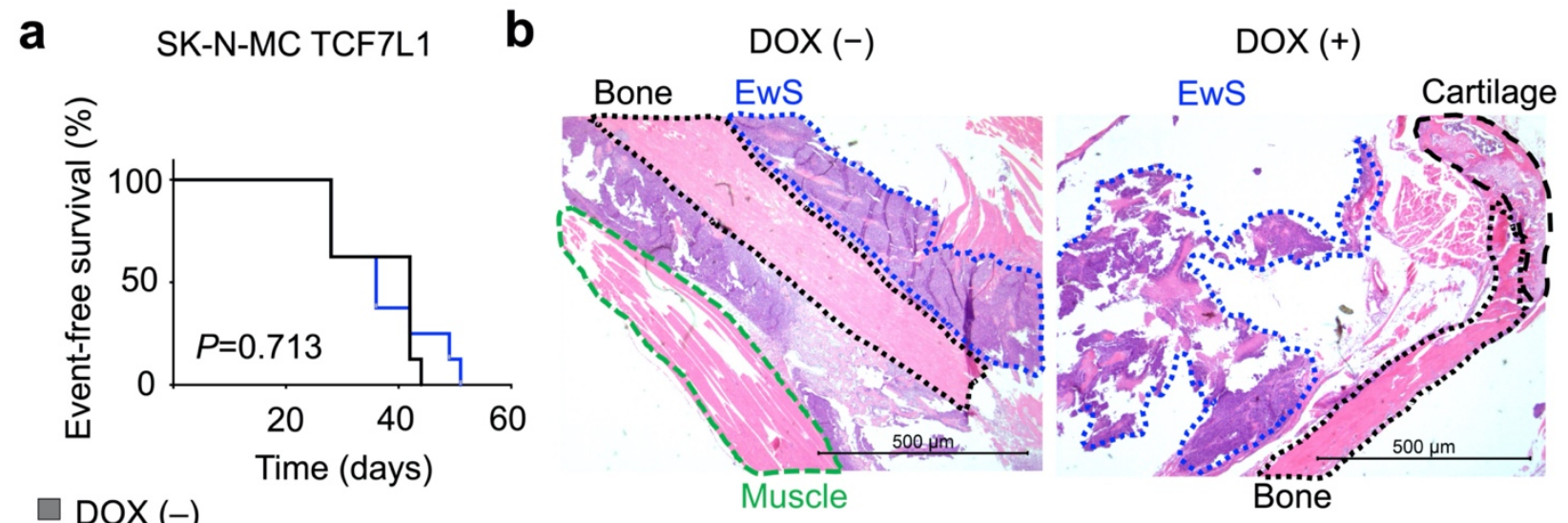

$\square \operatorname{DOX}(+)$

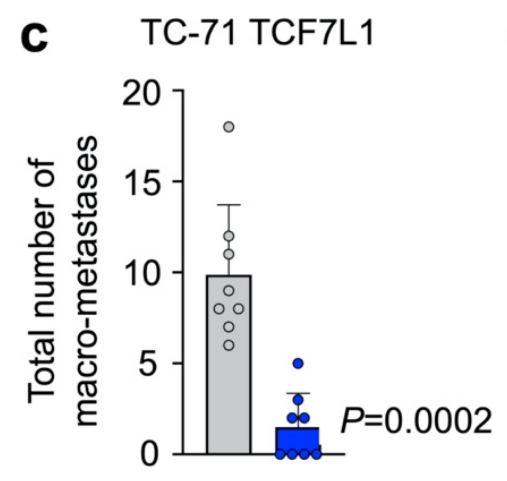

d

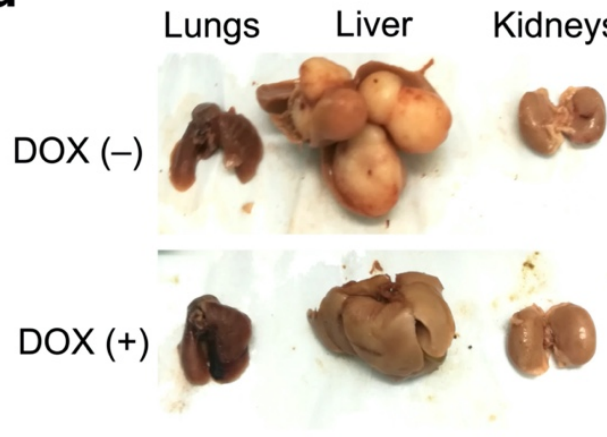

e

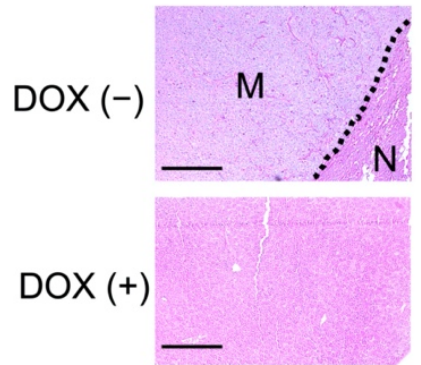

